\title{
Isohydricity of Two Different Citrus Species under Deficit Irrigation and Reclaimed Water Conditions
}

\author{
Cristina Romero-Trigueros *D, Jose María Bayona Gambín, Pedro Antonio Nortes Tortosa, Juan José \\ Alarcón Cabañero and Emilio Nicolás Nicolás \\ Irrigation Department, Centro de Edafología y Biología Aplicada del Segura, CSIC, P.O. Box 164, \\ 30100 Murcia, Spain; jmbayona@cebas.csic.es (J.M.B.G.); panortes@cebas.csic.es (P.A.N.T.); \\ jalarcon@cebas.csic.es (J.J.A.C.); emilio@cebas.csic.es (E.N.N.) \\ * Correspondence: cromero@cebas.csic.es; Tel.: +34-968-396200; Fax: +34-968-396-213
}

Citation: Romero-Trigueros, C.; Gambín, J.M.B.; Nortes Tortosa, P.A.; Cabañero, J.J.A.; Nicolás, E.N. Isohydricity of Two Different Citrus Species under Deficit Irrigation and Reclaimed Water Conditions. Plants 2021, 10, 2121. https://doi.org/ 10.3390/plants10102121

Academic Editor: Janusz J. Zwiazek

Received: 26 August 2021

Accepted: 29 September 2021

Published: 6 October 2021

Publisher's Note: MDPI stays neutral with regard to jurisdictional claims in published maps and institutional affiliations.

Copyright: (c) 2021 by the authors. Licensee MDPI, Basel, Switzerland. This article is an open access article distributed under the terms and conditions of the Creative Commons Attribution (CC BY) license (https:/ / creativecommons.org/licenses/by/ $4.0 /)$.

\begin{abstract}
Citrus species are frequently subjected to water and saline stresses worldwide. We evaluated the effects of diurnal changes in the evaporative demands and soil water contents on the plant physiology of grapefruit and mandarin crops under saline reclaimed (RW) and transfer (TW) water conditions, combined with two irrigation strategies, fully irrigated (fI) and non-irrigated (nI). The physiological responses were different depending on the species. Grapefruit showed an isohydric pattern, which restricted the use of the leaf water potential $\left(\Psi_{1}\right)$ as a plant water status indicator. Its water status was affected by salinity (RW) and water stress (nI), mainly as the combination of both stresses (RW-nI); however, mandarin turned out to be relatively more tolerant to salinity and more sensitive to water stress, mainly because of its low hydraulic conductance (K) levels, showing a critical drop in $\Psi_{1}$ that led to severe losses of root-stem $\left(\mathrm{K}_{\text {root-stem }}\right)$ and canopy $\left(\mathrm{K}_{\text {canopy }}\right)$ hydraulic conductance in TW-nI. This behavior was not observed in RW-nI because a reduction in canopy volume as an adaptive characteristic was observed; thus, mandarin exhibited more anisohydric behavior compared to grapefruit, but isohydrodynamic since its hydrodynamic water potential gradient from roots to shoots $\left(\Delta \Psi_{\text {plant }}\right)$ was relatively constant across variations in stomatal conductance $\left(g_{s}\right)$ and soil water potential. The $g_{s}$ was considered a good plant water status indicator for irrigation scheduling purposes in both species, and its responses to diurnal VPD rise and soil drought were strongly correlated with $\mathrm{K}_{\text {root-stem. }} \mathrm{ABA}$ did not show any effect on stomatal regulation, highlighting the fundamental role of plant hydraulics in driving stomatal closure.
\end{abstract}

Keywords: ABA; grapefruit; hydraulic conductance; mandarin; saline stress; stomatal conductance; water relations; water stress

\section{Introduction}

Citrus species are some of the most important commercial fruit crops around the world, including in semi-arid Mediterranean regions [1], where the irrigation water is not always available due to water scarcity; therefore, many citrus orchards suffer severe drought periods [2]. In order to overcome this issue, the use of non-conventional water sources such as reclaimed water (RW), whose volume is progressively increasing, is an alternative for farmers [3]. Among the advantages of the agronomic use of RW is the availability of macronutrients $(\mathrm{N}, \mathrm{P}, \mathrm{K})$ as fertilizer, although there is a risk that these nutrients, for instance $\mathrm{NO}_{3}$, could be lost in the ecosystem through leaching [4]. The use of RW may, nevertheless, have risks for agriculture, since it could be highly saline; thus, inappropriate management of irrigation with RW can exacerbate problems of secondary salinization and soil degradation over the medium to long term, resulting in negative impacts on plant physiology, growth, and other factors [5-7]. Studies have shown that citrus plants in general are strongly affected by both drought and salinity, since $\mathrm{Cl}^{-}$and $\mathrm{Na}^{+}$can be phytotoxic $[5,8]$. The physiological effects of these stresses in citrus include, among others, a reduction of gas exchange [9] caused by a combination of factors. On the one hand, the availability of 
soil water and atmospheric vapor pressure are among the numerous environmental factors affecting the stomatal aperture in dry conditions (water-stressed citrus) [10]. The sensitivity to atmospheric vapor pressure deficit (VPD) is a primary strategy by which plants regulate gas exchange [11]. An increase in VPD or a reduction in soil water content leads to a decrease in stomatal conductance $\left(\mathrm{g}_{\mathrm{s}}\right)$ or a hydraulic cascade of water potential in the tree, which becomes larger and longer-lasting when high atmospheric water demand combines with soil water stress [12]. This ability of plants to regulate transpirational water loss and to minimize fluctuations in water potential defines plants as isohydric or anisohydric [13]. More isohydric species are prone to carbon starvation, while more anisohydric species are more likely to die from tissue desiccation via hydraulic failure [14] Notwithstanding, the precise physical mechanism by which $\mathrm{g}_{\mathrm{s}}$ and water potential are coordinated remains a matter of debate $[15,16]$. The isohydric-anisohydric behavior and its implications in the photosynthesis of different vine cultivars [17] and in the kinetics of stomatal opening of other woody species [18] have been studied; however, we have not found published studies that have defined this phenomenon in mandarin or grapefruit trees, although in general citrus plants are considered isohydric [19]. On the other hand, in salt-stressed citrus trees, decreased photosynthetic rates could be also associated with salt-induced reductions in $\mathrm{CO}_{2}$ diffusion to stomata, as was reported earlier [20]. It has been proven that being exposed to salt may affect plant metabolism through (i) a specific ion effect, causing a gradual accumulation of toxic $\mathrm{Cl}^{-}$and $\mathrm{Na}^{+}$levels in aerial parts when no compartmentation of ions in the vacuole takes place, or through (ii) an osmotic effect, causing a water deficit. One of the main mechanisms that plants use to adapt to osmotic stress is osmotic adjustment (OA), which can maintain the positive leaf turgor, also named as pressure potential $\left(\Psi_{\mathrm{P}}\right)$, required to keep stomata open and sustain gas exchange [21], since stomatal closure could be affected by changes in the dynamic guard cells $\Psi_{\mathrm{P}}$ via feedback regulation [22]. Moreover, the role of hormone abscisic acid (ABA) in regulating $\mathrm{g}_{\mathrm{s}}$ is also an enduring controversy $[23,24]$. Although so far ABA appears to be the main factor involved in regulation of stomatal closure under water stress [25-27], there is considerable evidence that plants are able to respond directly to hydraulic signals caused by water deficit $[28,29]$. The hydraulic signals may be involved in responses of stomata to decrease water potential $[30,31]$, as cited above, or in the reduction of hydraulic conductance (K) during stress [32]. It has been demonstrated that seasonal shifts in $\mathrm{K}$ contribute to changes in $\mathrm{g}_{\mathrm{s}}$ [33]; however, it is unclear whether naturally occurring diurnal changes in K influence stomata [34].

Some of the responses described so far do not always occur simultaneously in citrus species, as some are rootstock dependent [35-37]; thus, the tolerance or sensitivity to drought and salinity is determined by the rootstock $[38,39]$, while its importance under the interaction of both stresses has not been reported yet to our knowledge. Further, studies that have evaluated tolerances in woody crops after extended periods of time applying these stresses are few in number because of the cost and time required. Consequently, understanding how saline and water stresses affect the dynamics of plant-atmosphere vapor exchange through its diurnal effects on $\mathrm{g}_{\mathrm{s}}[40]$ is important within the context of climate change increasing drought [41] and VPD [11] occurrence worldwide.

This study aims to evaluate the effects of long-term irrigation with saline RW and of the total suppression of irrigation for a period, as well as the combination of both stresses (saline and water), on diurnal changes in the physiology (water relations, phytotoxic elements, hydraulic conductance, ABA) of two citrus species with different rootstocks and productive potential, namely grapefruit [42] and mandarin [43], under field conditions. Additionally, we assess the stomatal response to environmental and physiological factors with the aim of finding useful indicators of plant water status for irrigation scheduling purposes. A fundamental aspect is to characterize the near isohydric or anisohydric behavior of both species. We hypothesize that the most physiologically affected treatment will be the one that combines both stresses, and in the case that both citrus species are isohydric, $g_{s}$ would be a better indicator than $\Psi_{1}$. 


\section{Results}

2.1. Effects of the Irrigation Strategies on Water Relations, Hydraulic Conductance, and ABA

The fully irrigated (fI) treatments of the grapefruit and mandarin crops resulted in similar $\Psi_{1}$ values throughout the day regardless of the water quality, although in grapefruit crops the RW-fI values were slightly lower than for control (TW-fI). The non-irrigated (nI) treatments for both crops resulted in lower $\Psi_{1}$ values than control at each sampling point. The most stressed treatments were RW-nI in grapefruit and TW-nI in mandarin, with the latter reaching values of about $-3.8 \mathrm{MPa}$ (Figure $1 \mathrm{~A}, \mathrm{~B})$. The $\Psi_{1}$ measured at predawn (henceforth $\Psi_{\text {soil }}$ ) was reduced in the $\mathrm{nI}$ treatments of both crops and also in RW-fI of grapefruit.

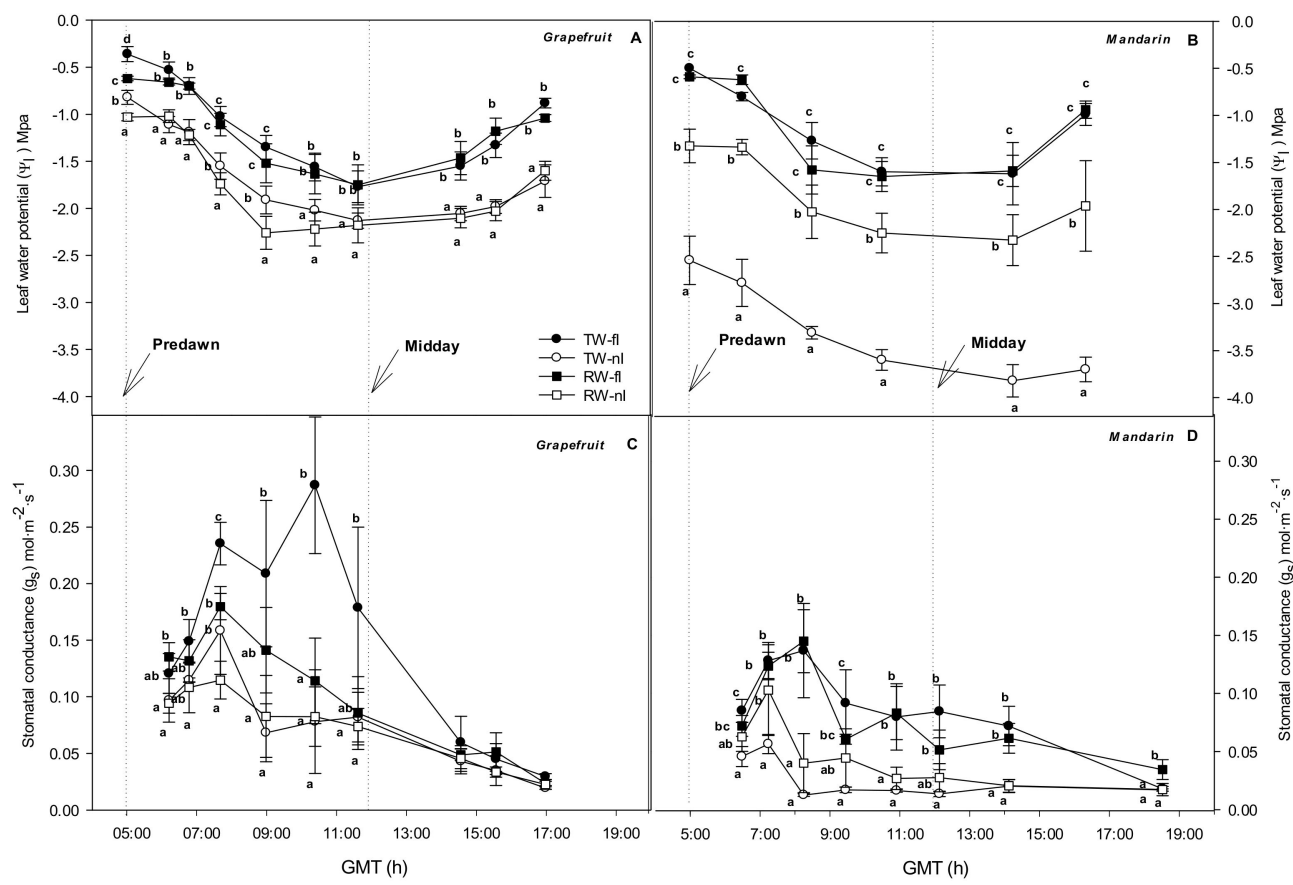

Figure 1. Daily evolution of leaf water potential $\left(\Psi_{1}\right)(\mathbf{A}, \mathbf{B})$ and stomatal conductance $\left(g_{s}\right)(\mathbf{C}, \mathbf{D})$ for each treatment (TW-fI: transfer water-fully irrigated; TW-nI: transfer water-non-irrigated; RW-fI: reclaimed water-fully irrigated; RW-nI: reclaimed water-non-irrigated) and crop (grapefruit and mandarin). Each point is the average \pm standard deviation of 4 blocks, collected at 248 DOY. Different letters indicate significant differences at $p<0.05$, as assessed using Tukey's test.

Regarding gas exchange (Figure 1C,D), in grapefruit, control trees reached the daily maximal value of $\mathrm{g}_{\mathrm{s}}\left(0.287 \mathrm{~mol} \cdot \mathrm{m}^{-2} \cdot \mathrm{s}^{-1}\right)$ at midday $(10.30 \mathrm{GMT})$; however, for the rest of stressed treatments, the maximal values were observed earlier (07.40 GMT) and were significantly lower than those of control ( $g_{s}$ reduced by $44.7,37.4$, and $60.0 \%$ for TW$\mathrm{nI}, \mathrm{RW}-\mathrm{fI}$, and RW-nI, respectively). In mandarin, control and RW-fI trees reached the daily maximal values of $\mathrm{g}_{\mathrm{s}}\left(0.141 \mathrm{~mol} \cdot \mathrm{m}^{-2} \cdot \mathrm{s}^{-1}\right)$ at around $08.15 \mathrm{GMT}$; however, similarly to grapefruit, the $\mathrm{nI}$ trees reached the daily maximal values of $\mathrm{g}_{\mathrm{s}}$ earlier (07.15 GMT), which were significantly lower than those of control $\left(g_{s}\right.$ reduced by 58.8 and $24.8 \%$ for TW-nI and RW-nI, respectively). Similar behaviors for both crops were observed over the rest of sampling that was carried out during the two months of irrigation suppression (Supplementary Figure S1). Overall, the treatments that were more affected by the irrigation strategies and daily VPD changes were: RW-nI in the grapefruit trees, as we hypothesized; TW-nI in mandarin trees (Figure 1, Figures S1 and S2). Grapefruit trees showed higher rates of $g_{s}$ than the mandarin trees.

Concerning the effects of the irrigation strategies on the $\Psi_{1}$ components (Figure 2), in grapefruit trees, the $\Psi_{\pi}$ values from all stressed treatments significantly decreased with respect to control at predawn (before the climatic conditions affected the plant water status) and at midday (except RW-fI). The treatment with the most negative $\Psi_{\pi}$ values was RW-nI. 
The $\Psi_{\mathrm{P}}$ values were similar in the fI treatments (RW-fI and TW-fI) and significantly lower in the $\mathrm{nI}$ treatments at predawn. No significant differences among any treatments were shown at midday, since the $\Psi_{P}$ values of the fI treatments significantly decreased (Figure 2A,B). In the mandarin crop, the $\Psi_{\pi}$ values of fI treatments (TW-fI and RW-fI) were similar at predawn according to $\Psi_{\text {soil }}$, although at midday the RW-fI values significantly decreased. The $\Psi_{\pi}$ values of the nI treatments were significantly lower than those of control at both sampling points, with the TW-nI treatment being the most affected. The $\Psi_{\mathrm{P}}$ values of RW-fI were significantly higher than the control at midday. On the contrary, the nI treatments showed significantly decreased $\Psi_{P}$ values, with TW-nI specifically showing the lowest $\Psi_{\mathrm{P}}$ values, which were near zero at midday (Figure $2 \mathrm{C}, \mathrm{D}$ ). In general, the mandarin trees presented lower $\Psi_{\pi}$ and higher $\Psi_{P}$ values than the grapefruit trees.

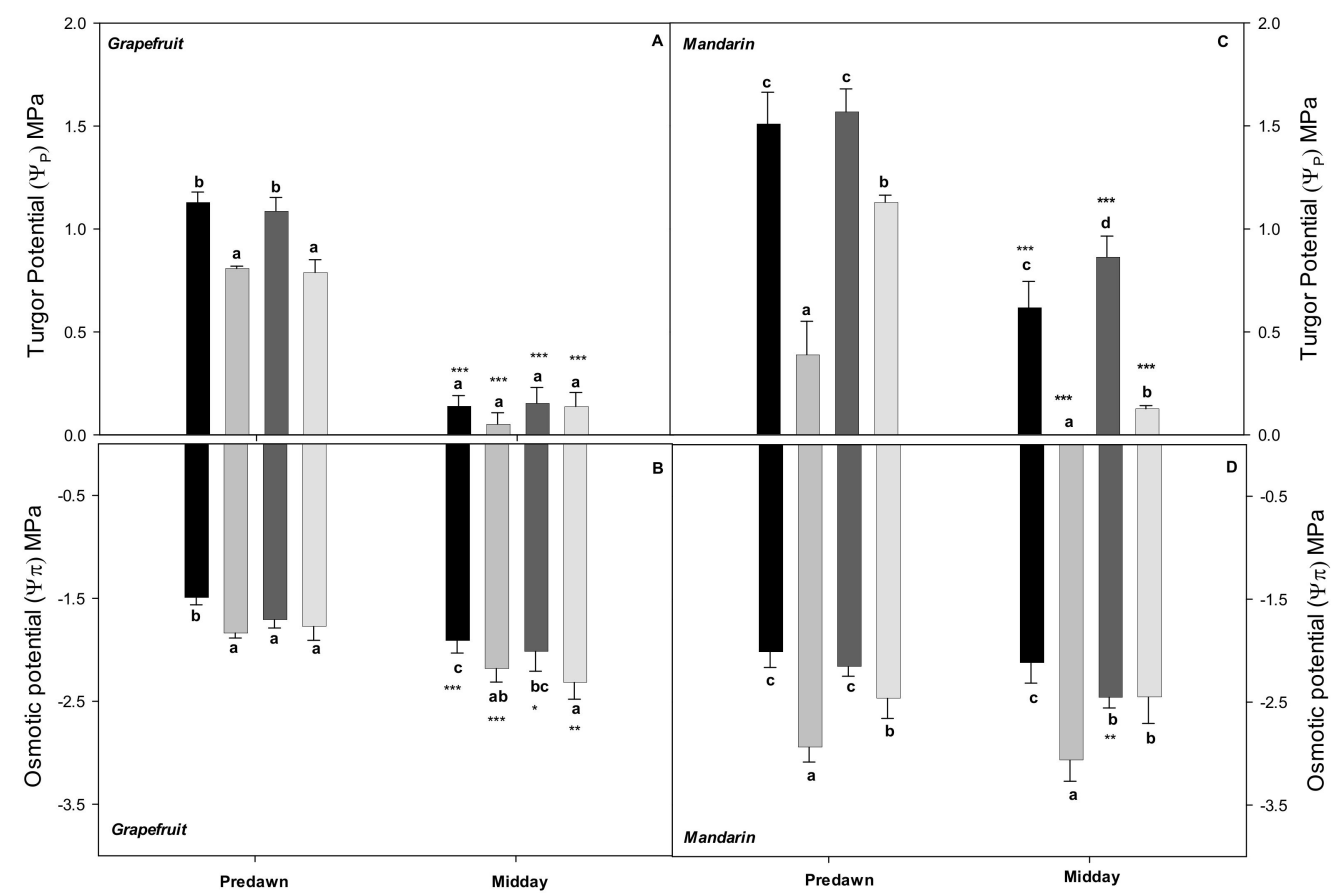

Figure 2. Leaf turgor potential $\left(\Psi_{\mathrm{P}}\right)(\mathbf{A}, \mathbf{C})$ and leaf osmotic potential $\left(\Psi_{\pi}\right)(\mathbf{B}, \mathbf{D})$ at predawn and midday for each treatment (TW-fI: transfer water-fully irrigated; TW-nI: transfer water-nonirrigated; RW-fI: reclaimed water-fully irrigated; RW-nI: reclaimed water-non-irrigated) and crop (grapefruit and mandarin). Each value is the average of 4 blocks, collected at 248 DOY. The bars denote the standard deviation of the mean. Within each sampling and crop, different letters indicate significant differences at $p<0.05$, as assessed using Tukey's test. Asterisks indicate significant differences between time samplings for the same treatment according to repeated measures ANOVA $\left({ }^{* * *} p<0.001,{ }^{* *} p<0.01, * p<0.05\right)$.

According to $\Psi_{100 \mathrm{~s}}$ (Table 1), a moderate OA resulted from the RW-nI treatment $(0.27 \mathrm{MPa})$ of grapefruit trees and from both $\mathrm{nI}$ treatments $(0.25$ and $0.15 \mathrm{MPa}$ for $\mathrm{TW}-\mathrm{nI}$ and RW-nI, respectively) of mandarin. Regarding phytotoxic elements (Table 1), in grapefruit there were no significant differences in the $\mathrm{Cl}^{-}$and $\mathrm{Na}^{+}$contents among treatments, although the values tended to be higher in the RW trees with respect to the control (by 29\% and $32 \%$ for $\mathrm{Cl}^{-}$and $\mathrm{Na}^{+}$, respectively, in RW-fI; by $48 \%$ for $\mathrm{Na}^{+}$in RW-nI). In mandarin, the RW trees significantly increased the $\mathrm{Cl}^{-}$(by 255\% and 205\% for RW-fI and RW-nI, respectively) and $\mathrm{Na}^{+}$(by 52 and 59\% for RW-fI and RW-nI, respectively) values versus the control, although only the $\mathrm{Cl}^{-}$changes were significant. 
Table 1. Leaf osmotic potential at full turgor $\left(\Psi_{100 \mathrm{~s}}\right)$ at midday, osmotic adjustment (OA), and leaf phytotoxic element values for each treatment and crop (grapefruit and mandarin). Each value is the average \pm standard deviation of 4 blocks collected at 248 DOY. Within each column, different letters indicate significant differences at $p<0.05$, as assessed using Tukey's test.

\begin{tabular}{|c|c|c|c|c|c|}
\hline Crop & Treatment & $\Psi_{100 \mathrm{~s}}(\mathrm{MPa})$ & OA (MPa) & $\mathrm{Cl}^{-}(\%)$ & $\mathrm{Na}^{+}(\%)$ \\
\hline \multirow{4}{*}{ 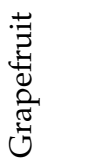 } & TW-fI & $-1.59 \pm 0.13 a$ & - & $0.44 \pm 0.02 \mathrm{a}$ & $0.050 \pm 0.005 a$ \\
\hline & TW-nI & $-1.45 \pm 0.11 \mathrm{a}$ & -0.14 & $0.32 \pm 0.11 \mathrm{a}$ & $0.036 \pm 0.004 \mathrm{a}$ \\
\hline & RW-fI & $-1.39 \pm 0.21 \mathrm{a}$ & -0.20 & $0.57 \pm 0.02 \mathrm{a}$ & $0.066 \pm 0.026 a$ \\
\hline & RW-nI & $-1.86 \pm 0.01 \mathrm{~b}$ & 0.27 & $0.40 \pm 0.28 \mathrm{a}$ & $0.074 \pm 0.038 \mathrm{a}$ \\
\hline \multirow{4}{*}{ 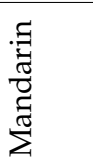 } & TW-fI & $-1.73 \pm 0.11 \mathrm{a}$ & & $0.18 \pm 0.02 \mathrm{a}$ & $0.046 \pm 0.010 \mathrm{a}$ \\
\hline & TW-nI & $-1.98 \pm 0.08 \mathrm{~b}$ & 0.25 & $0.15 \pm 0.07 \mathrm{a}$ & $0.055 \pm 0.020 \mathrm{a}$ \\
\hline & RW-fI & $-1.69 \pm 0.10 \mathrm{a}$ & 0.04 & $0.64 \pm 0.08 b$ & $0.070 \pm 0.009 a$ \\
\hline & RW-nI & $-1.88 \pm 0.03 \mathrm{ab}$ & 0.15 & $0.55 \pm 0.05 b$ & $0.073 \pm 0.006 \mathrm{a}$ \\
\hline
\end{tabular}

TW-fI: transfer water-fully irrigated; TW-nI: transfer water-non-irrigated; RW-fI: reclaimed water-fully irrigated; RW-nI: reclaimed water-non-irrigated.

Plant hydraulic conductance was significantly affected by water amount. In grapefruit, there was a significant decrease in the Kroot-stem of the both nI treatments (TW-nI and RW$\mathrm{nI})$ and in the $\mathrm{K}_{\text {canopy }}$ of RW-fI, with respect to the control (Table 2). In mandarin, there was an important decrease in the $\mathrm{K}_{\text {root-stem }}$ of both nI treatments (TW-nI and RW-nI) and in the $\mathrm{K}_{\text {canopy }}$ of TW-nI versus control.

Table 2. Root-stem hydraulic conductance $\left(\mathrm{K}_{\text {root-stem }}\right)$ and canopy hydraulic conductance $\left(\mathrm{K}_{\text {canopy }}\right)$ values for each treatment and crop (grapefruit and mandarin). Each value is the average \pm standard deviation of 4 blocks, collected at 248 DOY. Within each column, different letters indicate significant differences at $p<0.05$, as assessed using Tukey's test. In two-way ANOVA, including water quality $(\mathrm{Qw})$ and amount (Aw) as factors, ${ }^{* * *} p<0.001,{ }^{* *} p<0.01,{ }^{*} p<0.05$; ns: not significant.

\begin{tabular}{|c|c|c|c|}
\hline Crop & Treatment & $\begin{array}{c}\mathrm{K}_{\text {root-stem }} \\
\left(\mathrm{mol} \cdot \mathrm{MPa}^{-1} \cdot \mathrm{m}^{-2} \cdot \mathrm{s}^{-1}\right)\end{array}$ & $\begin{array}{c}\mathrm{K}_{\text {canopy }} \\
\left(\mathrm{mol} \cdot \mathrm{MPa}^{-1} \cdot \mathrm{m}^{-2} \cdot \mathrm{s}^{-1}\right)\end{array}$ \\
\hline \multirow{4}{*}{ 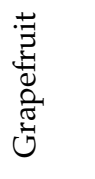 } & TW-fI & $4.51 \pm 0.28 b$ & $8.93 \pm 1.81 b$ \\
\hline & TW-nI & $2.89 \pm 0.29 a$ & $8.47 \pm 2.26 b$ \\
\hline & RW-fI & $4.54 \pm 0.22 b$ & $4.26 \pm 0.93 a$ \\
\hline & RW-nI & $2.23 \pm 0.20 \mathrm{a}$ & $9.65 \pm 3.20 b$ \\
\hline \multirow{3}{*}{ 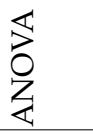 } & Qw & ns & ns \\
\hline & Aw & $*$ & $*$ \\
\hline & $\mathrm{Qw} * \mathrm{Aw}$ & ns & * \\
\hline \multirow{4}{*}{ 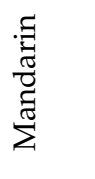 } & TW-fI & $4.87 \pm 0.81 b$ & $2.47 \pm 0.81 b$ \\
\hline & TW-nI & $0.69 \pm 0.11 \mathrm{a}$ & $1.51 \pm 0.23 \mathrm{a}$ \\
\hline & RW-fI & $5.30 \pm 0.38 b$ & $2.48 \pm 0.43 b$ \\
\hline & RW-nI & $0.86 \pm 0.18 \mathrm{a}$ & $2.41 \pm 1.26 \mathrm{~b}$ \\
\hline \multirow{3}{*}{$\begin{array}{l}\text { 岁 } \\
\text { ठ } \\
\text { Z }\end{array}$} & Qw & ns & ns \\
\hline & Aw & $* * *$ & $* *$ \\
\hline & $\mathrm{Qw} * \mathrm{Aw}$ & ns & ns \\
\hline
\end{tabular}

Across treatments, in grapefruit trees the $\mathrm{K}_{\text {canopy }}$ was higher than the $\mathrm{K}_{\text {root-stem }}$ (the average values were 7.8 and $3.5 \mathrm{~mol} \cdot \mathrm{MPa}^{-1} \cdot \mathrm{m}^{-2} \cdot \mathrm{s}^{-1}$ for the $\mathrm{K}_{\text {canopy }}$ and $\mathrm{K}_{\text {root-stem, }}$ respectively). On the contrary, in mandarin trees the average $\mathrm{K}_{\text {root-stem values were slightly }}$ higher than the $\mathrm{K}_{\text {canopy }}$ values $\left(2.9\right.$ and $2.2 \mathrm{~mol} \cdot \mathrm{MPa}^{-1} \cdot \mathrm{m}^{-2} \cdot \mathrm{s}^{-1}$ for the $\mathrm{K}_{\text {root-stem }}$ and $\mathrm{K}_{\text {canopy, }}$, respectively). Overall, the hydraulic conductance of mandarin crop was lower than that of grapefruitcrop, with mandarin trees also being more affected by water stress

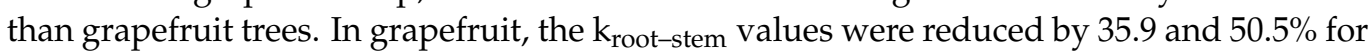


TW-nI and RW-nI, respectively. In mandarin, the $\mathrm{k}_{\text {root-stem }}$ and $\mathrm{k}_{\text {canopy }}$ values were reduced by 85.2 and $38.7 \%$ for TW-nI and by 82.3 and $2.4 \%$ for RW-nI, respectively, versus control).

Regarding the phytohormonal signals of grapefruit trees, RW-nI resulted in lower $A B A$ values than the rest of the treatments at both sampling points, although they were only significant at predawn. In mandarin trees, the ABA content was significantly lower for TW-nI at midday (Figure 3A,B); thus, decreased ABA levels were observed for the most water-stressed treatments (RW-nI in grapefruit and TW-nI in mandarin, Figure 1A,B).

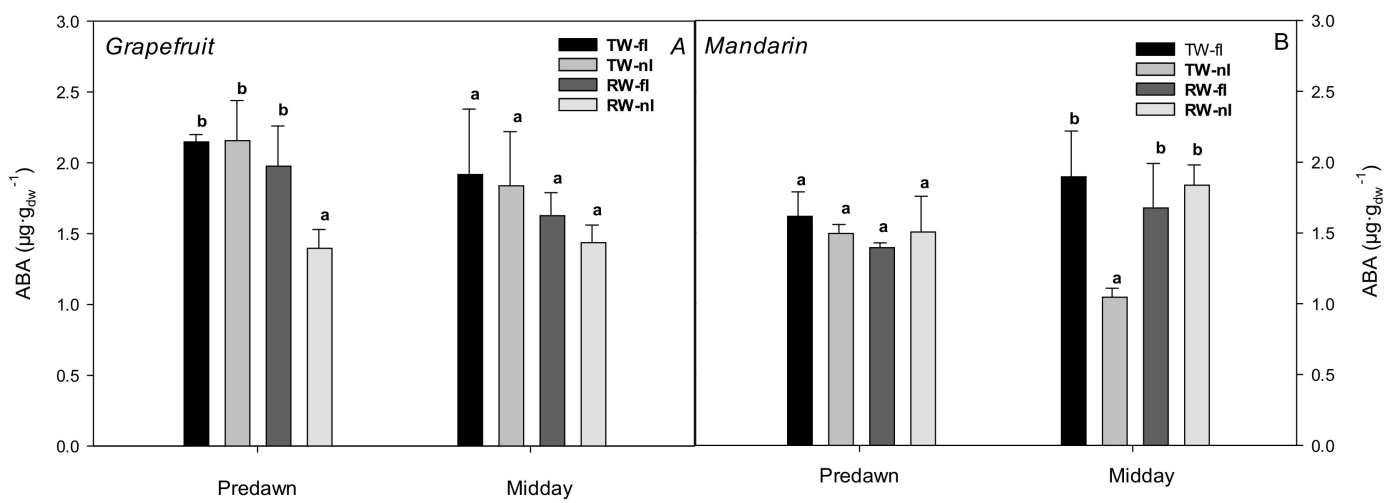

Figure 3. Leaf ABA content for grapefruit (A) and mandarin (B) and for each treatment (TW-fI: transfer water-fully irrigated; TW-nI: transfer water-non-irrigated; RW-fI: reclaimed water-fully irrigated; RW-nI: reclaimed water-nonirrigated). Each value is the average of 4 blocks, collected at 248 DOY. The bars denote the standard deviations of the mean. Within each sampling and crop, different letters indicate significant differences at $p<0.05$, as assessed using Tukey's test.

\subsection{Relationship between Stomata and Environmental and Plant Physiological Factors}

Multiple variables that can influence the stomatal response have been studied, which are classified here as environmental (soil water content and VPD) and physiological (nonhydraulic or hydraulic) factors. The group of non-hydraulic variables includes chemical signals such as the ABA, while the group of hydraulic variables includes $\Psi_{1}, T_{1}, \Psi_{\pi}, \Psi_{P}$, and $\mathrm{K}$.

Regarding environmental factors, we found that the $g_{s}$ was significantly correlated with the $\Psi_{\text {soil }}(p<0.001)$ (Figure 4A,B) and VPD $(p<0.001)$ (Figure 4C,D) in both crops. The linear regression plot for mandarin trees showed a gentler slope than that of grapefruit trees due to the $\Psi_{\text {soil }}$ reaching very negative values and to the low $g_{s}$ of mandarin versus grapefruit trees. The regression lines between $\mathrm{g}_{\mathrm{s}}$ and VPD also showed different slopes according to treatment. In grapefruit trees, the slope was significantly steeper in the control than in the rest of treatments (TW-fI $>$ RW-fI $>$ TW-nI $>$ RW-nI). Likewise, the slopes for mandarin plants were steeper in the fI treatments than in nI treatments (TW-fI $>$ RW-fI $>$ RW-nI > TW-nI), with RW-fI and TW-fI being quite similar (0.033 and 0.025); therefore, in both crops, the stomatal closure was more sensitive to VPD variations, mainly when soil water was not a very limiting factor. It is noteworthy that when plotting $\mathrm{g}_{\mathrm{s}}$ and VPD data measured during the whole growth season between 06.00 and 08.00 GMT, no significant correlations between the parameters were found in any crop. 

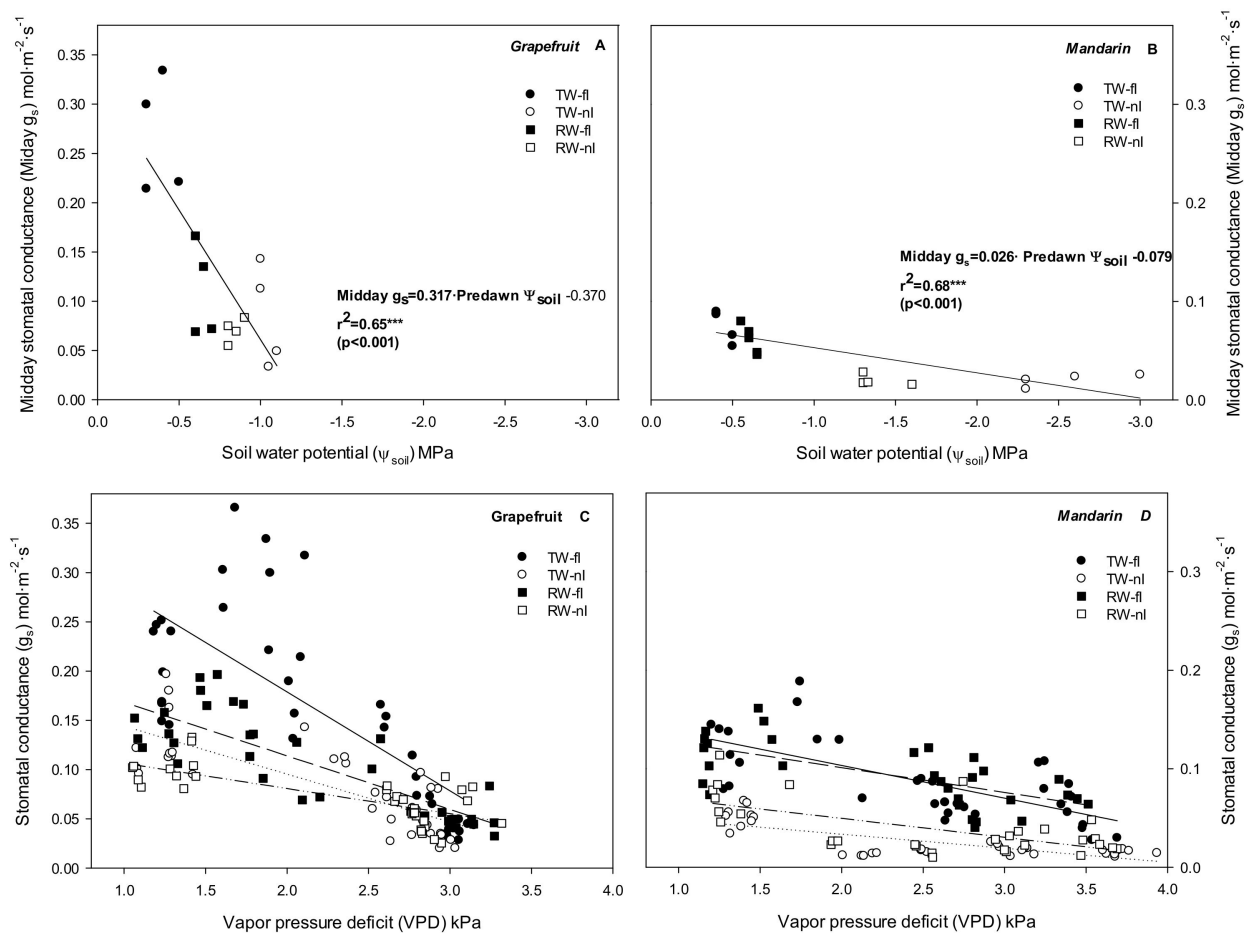

Figure 4. Correlations between midday stomatal conductance (Midday $\mathrm{g}_{\mathrm{s}}$ ) and soil water potential $\left(\Psi_{\text {soil }}\right)$ values $(\mathbf{A}, \mathbf{B})$ and between stomatal conductance $\left(\mathrm{g}_{\mathrm{s}}\right)$ and vapor pressure deficit $(\mathrm{VPD})$ values (C,D) for each treatment (TW-fI: transfer water-fully irrigated; TW-nI: transfer water-non-irrigated; RW-fI: reclaimed water-fully irrigated; RW-nI: reclaimed water-non-irrigated) and crop (grapefruit and mandarin). Each point is the average of the two central trees of each block. The regression lines between $g_{s}$ and VPD for grapefruit plants were $(C)$ : TW-fI: $g_{s}=-0.100 \cdot V P D+0.170 ; r^{2}=0.53 * * *$ $(p<0.001)$; TW-nI: $\mathrm{g}_{\mathrm{s}}=-0.049 \cdot \mathrm{VPD}+0.223 ; \mathrm{r}^{2}=0.61 * * *(p<0.001) ; \mathrm{RW}-\mathrm{fI}: \mathrm{g}_{\mathrm{s}}=-0.054 \cdot \mathrm{VPD}+0.193 ;$ $\mathrm{r}^{2}=0.69^{* * *}(p<0.001) ; \mathrm{RW}-\mathrm{nI}: \mathrm{g}_{\mathrm{s}}=-0.026 \cdot \mathrm{VPD}+0.132 ; \mathrm{r}^{2}=0.52^{* * *}(p<0.001)$. The regression lines between $g_{s}$ and VPD for mandarin plants were (D): TW-fI: $g_{s}=-0.033 \cdot V P D+0.170 ; \mathrm{r}^{2}=0.48^{* * *}$ $(p<0.001)$; TW-nI: $\mathrm{g}_{\mathrm{s}}=-0.014 \cdot \mathrm{VPD}+0.062 ; \mathrm{r}^{2}=0.55^{* * *}(p<0.001) ; \mathrm{RW}-\mathrm{fI}: \mathrm{g}_{\mathrm{s}}=-0.025 \cdot \mathrm{VPD}+0.152 ;$ $\mathrm{r}^{2}=0.42^{* * *}(p<0.001) ;$ RW-nI: $\mathrm{g}_{\mathrm{s}}=-0.019 \cdot \mathrm{VPD}+0.088 ; \mathrm{r}^{2}=0.39 * * *(p<0.001)$.

Regarding physiological plant factors, the ABA results (non-hydraulic factor) did not correlate with $\mathrm{g}_{\mathrm{s}}$ for any sampling, treatment, or crop. With respect to the physiological hydraulic factors, when soil moisture was not a limiting factor, regardless of water quality, the $\Psi_{1}$ did not exert much control over $g_{s}$ with the diurnal increase in VPD. In contrast, the $\mathrm{nI}$ treatments of both crops presented sensitive $g_{s}$ responses to changes in $\Psi_{1}$ throughout the day (Figure 5A,B). 


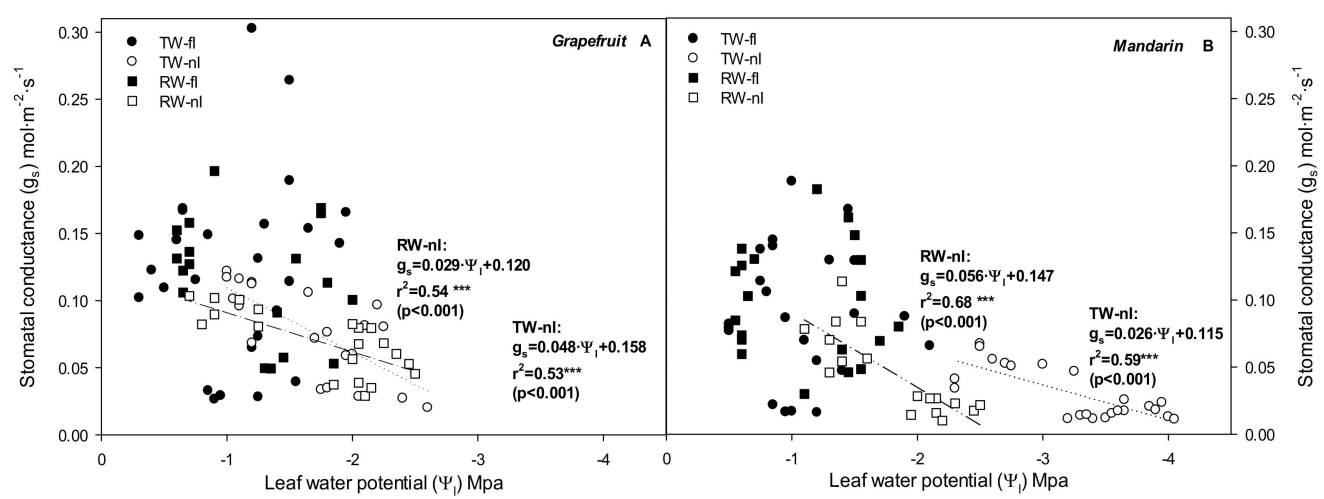

Figure 5. Correlations between stomatal conductance $\left(g_{s}\right)$ and leaf water potential $\left(\Psi_{1}\right)$ values for grapefruit (A) and mandarin (B) and all treatments. Each point is the average of the two central trees of each block.

When only midday data were used, both crops showed positive significant correlations between midday $\Psi_{1}$ and midday $\mathrm{g}_{\mathrm{s}}$ ( $p<0.02$ for grapefruit and $p<0.001$ for mandarin) (Figure 6A,B) and between midday $\Psi_{1}$ and $\Psi_{\text {soil }}(p<0.001$ both crops) (Figure 6C,D); however, the hydrodynamic (transpiration-induced) water potential gradient from roots to shoots $\left(\Delta \Psi_{\text {plant }}\right)$ was relatively constant in the mandarin crop. In fact, linear regression of midday $\Delta \Psi_{\text {plant }}$ versus midday $g_{s}$ or even $\Psi_{\text {soil }}$ produced completely horizontal lines in mandarin trees (Figure 6B,D). This behavior was not observed in grapefruit trees (Figure 6A,C).
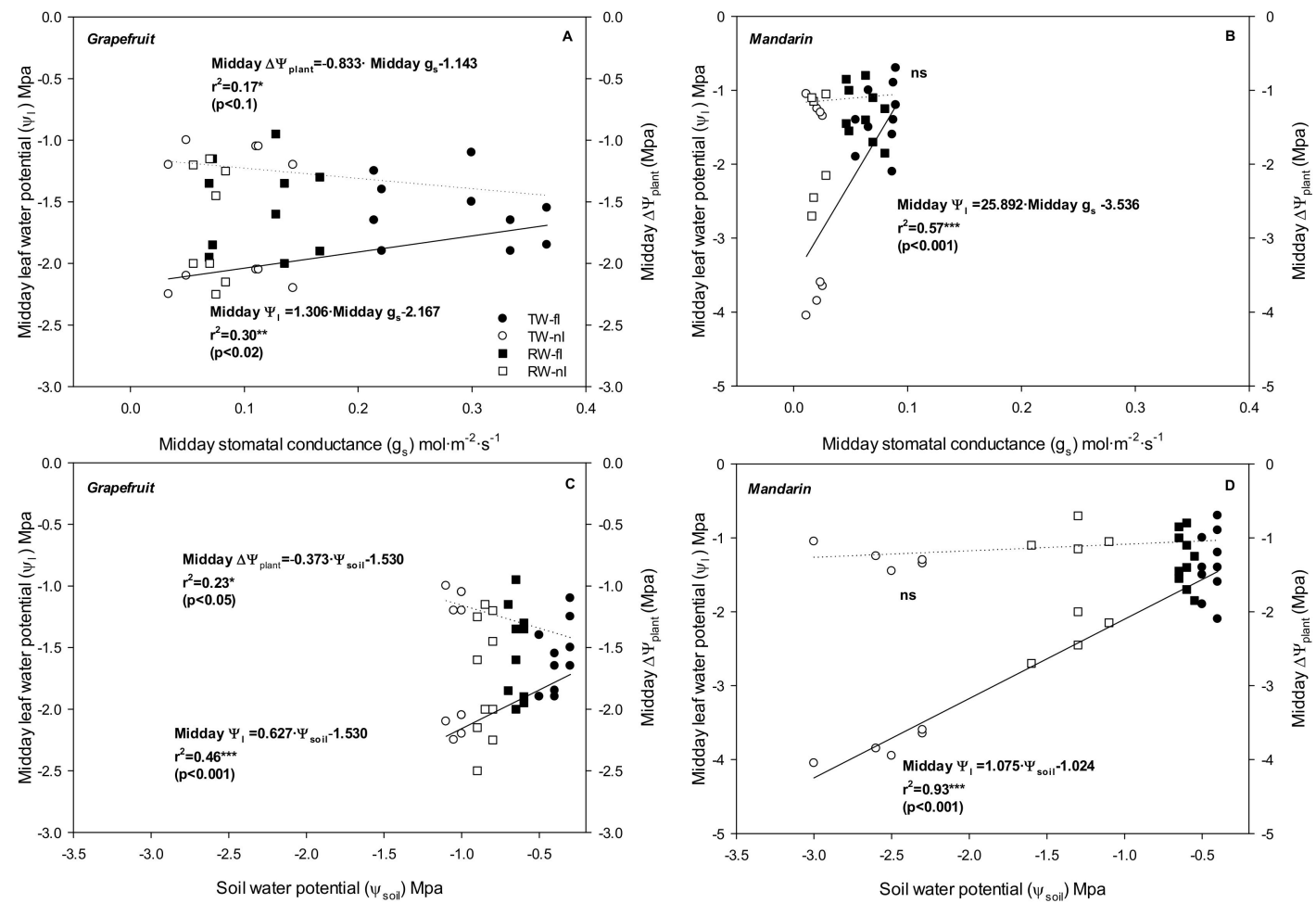

Figure 6. Correlations of midday leaf water potential (midday $\Psi_{1}$ ) with midday stomatal conductance (midday $g_{s}$ ) (continuous lines), of midday hydrodynamic (transpiration-induced) water potential gradient from roots to shoots (midday $\Delta \Psi_{\text {plant }}$ ) with midday $g_{\mathrm{s}}$ (dash lines) $(\mathbf{A}, \mathbf{B})$, and of midday $\Psi_{1}$ with soil water potential $\left(\Psi_{\text {soil }}\right)$ (continuous lines) and midday $\Delta \Psi_{\text {plant }}$ with $\Psi_{\text {soil }}$ (dash lines) (C,D) for all treatments and both crops (grapefruit and mandarin).

A positive relationship between $\mathrm{g}_{\mathrm{s}}$ and $\mathrm{T}_{1}$ was found when only data below $30{ }^{\circ} \mathrm{C}$ were plotted $\left(\mathrm{r}^{2}=0.51, p<0.005\right.$ and $\mathrm{r}^{2}=0.27, p<0.005$ for grapefruit and mandarin, respectively). This was due to the fact that from 20 to $30{ }^{\circ} \mathrm{C}$, the VPD and $\mathrm{T}_{1}$ were linearly 
correlated (Figure S3), while from 30 to $40{ }^{\circ} \mathrm{C}$, the VPD increased quickly and the $\mathrm{g}_{\mathrm{s}}$ was widely dispersed, depending on the treatment. In general, the VPD and $T_{1}$ values were greater in mandarin than in grapefruit trees.

Finally, the stomatal response to the hydraulic conductance at midday was also studied (Figure 7). In grapefruit, the $g_{s}$ was significantly correlated with the $K_{\text {root-stem }}\left(r^{2}=0.58\right.$, $p<0.001)$, while with the $\mathrm{K}_{\text {canopy }}$, this was true only for the RW-fI trees $\left(\mathrm{r}^{2}=0.63, p<0.05\right)$. In mandarin plants, $\mathrm{g}_{\mathrm{s}}$ was correlated with both $\mathrm{K}_{\text {root-stem }}\left(\mathrm{r}^{2}=0.92, p<0.001\right)$ and $\mathrm{K}_{\text {canopy }}$ $\left(\mathrm{r}^{2}=0.55, p<0.001\right)$. Across species, a significant correlation between $\mathrm{g}_{\mathrm{s}}$ and $\mathrm{K}_{\text {root-stem }}$ $\left(\mathrm{r}^{2}=0.50, p<0.001\right)$ was found, but not for $\mathrm{g}_{\mathrm{s}}$ and $\mathrm{K}_{\text {canopy }}$.

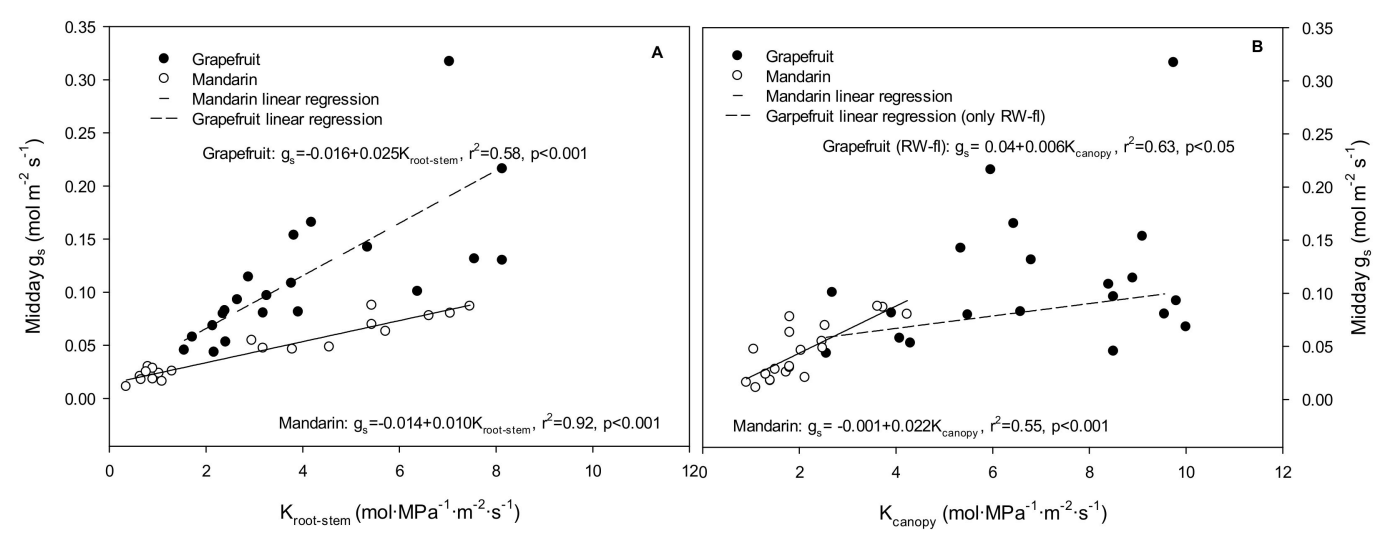

Figure 7. Correlations between midday stomatal conductance (midday $\mathrm{g}_{\mathrm{s}}$ ) and (A) root-stem hydraulic conductance ( $\left.\mathrm{K}_{\text {root-stem }}\right)$ and $(B)$ canopy hydraulic conductance $\left(\mathrm{K}_{\text {canopy }}\right)$ for each treatment (TW-fI: transfer water-fully irrigated; TW-nI: transfer water-non-irrigated; RW-fI: reclaimed water—fully irrigated; RW-nI: reclaimed water-non-irrigated) and crop (grapefruit and mandarin).

\section{Discussion}

\subsection{Water Relations of the Grapefruit and Mandarin Crops under Saline and Water Stresses}

Mandarin and grapefruit presented different hydraulic conductance levels. Some studies reported $\mathrm{K}$ data for citrus plants with different rootstocks but using seedlings $[36,44,45]$ or pots [46]. The higher hydraulic capacity, mainly of the canopy, observed in grapefruit compared to mandarin trees was explained by the high leaf gas exchange levels according to [47], who reported that species with large photosynthetic capacity must show a high hydraulic capacity to cope with the high $\mathrm{g}_{\mathrm{s}}$ values required to avoid diffusional limitations to photosynthesis. Similar results were found by [48] for almond and olive plants, two species with different $\mathrm{K}$ values. Additionally, the $\mathrm{K}_{\text {root-stem }}$ values were more vulnerable to cavitation than the $\mathrm{K}_{\text {canopy }}$ values in both species, in agreement with [49], who showed that the rootstem segment is more prone to this process. The midday depression observed in $\mathrm{g}_{\mathrm{s}}$ is common in many plant species [50]. It has been associated with variations in the midday stem water status [51], supporting the idea that the stomatal response to VPD is strongly related to the hydraulic characteristics of the whole plant, as well as the leaf [52]. Non-stomatal limitations such as decreased mesophyll conductance to $\mathrm{CO}_{2}$ may also be partly responsible for the midday depression, although it has been not demonstrated to predominate [53]. In our work, the higher the water deficit was, the lower the $g_{s}$ values that were found and the earlier in the morning the maximum $\mathrm{g}_{\mathrm{s}}$ was reached, in line with [54].

The strategies and resistance mechanisms developed by plants under the different irrigation strategies depended on the crop, which are described below.

In the grapefruit crop, the trees under water stress and previously irrigated with TW (TW-nI) showed a reduction of $0.5 \mathrm{MPa}$ in $\Psi_{\text {soil }}$. This resulted in a 35\% drop in the

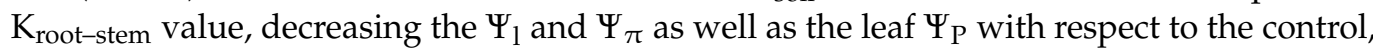
in accordance with [6], thereby affecting the gas exchange. When trees were fully irrigated but with saline RW, the $\Psi_{\text {soil }}$ was also reduced, although to a lesser extent $(0.3 \mathrm{MPa})$. In this 
case, this was not due to water restrictions but to the soil salt accumulation from the RW source, which caused an osmotic effect in the root zone, hindering the absorption of water by the trees [55]; however, unlike TW-nI, this $\Psi_{\text {soil }}$ drop caused cavitation of conductive elements of the canopy and the subsequent loss of the $\mathrm{K}_{\text {canopy }}$, in line with [56], which was the main cause of the decrease in $\mathrm{g}_{\mathrm{s}}$ and was linked to $\mathrm{Cl}^{-}$and $\mathrm{Na}^{+}$toxicity. The $g_{s}$ reduction largely prevented $\Psi_{1}$ and $\Psi_{\pi}$, from being affected, according to other studies on citrus plants [7], allowing the leaf turgor to be maintained at similar levels to the control trees. The fact that $\Psi_{1}$ did not decline measurably with $g_{s}$ showed that stomata responded quickly and sensitively enough to hydraulic signals to achieve near-homeostasis in $\Psi_{1}$ [34]. Consequently, $\Psi_{1}$ was not a good indicator of actual plant water status for irrigation scheduling, differing from other fruit trees $[57,58]$. In the RW-nI treatment, the $\mathrm{g}_{\mathrm{s}}$ reduction was a little more pronounced than for TW-nI, since the combination of both stresses caused greater decreases in the $\Psi_{\text {soil }}$ (reduction of $0.7 \mathrm{MPa}$ ) and $\Psi_{1}$ throughout the day, giving rise to an important loss of $K_{\text {root-stem }}$ due to cavitation and embolism of xylem vessels [59]. Moreover, the Citrus macrophylla (grapefruit) rootstock lacked $\mathrm{Cl}^{-}$and $\mathrm{Na}^{+}$ under salinity conditions, in accordance with [60] and with the salt tolerance rankings of the rootstocks reported by other authors $[61,62]$. Low $\mathrm{Na}^{+}$and $\mathrm{Cl}^{-}$levels in the grapefruit trees irrigated with saline RW as compared to the control did not affect the vegetative growth (similar canopy volumes in all trees as were described in [42] and [63]) or yield [7], suggesting that this crop is a salt-stress-tolerant citrus [64].

In the mandarin crop, the trees under irrigation suppression (TW-nI) showed drastic reductions in the $\Psi_{\text {soil }}$ values ( $2 \mathrm{MPa}$ less than control), showing severe water stress with very negative $\Psi_{1}$ values achieved by means of decreases in $\Psi_{\pi}$, according to [65]. This made it difficult to take up water from the substrate, affecting the $\mathrm{K}_{\text {root-stem }}$ and $\mathrm{K}_{\text {canopy, }}$ and causing a strong reduction in $\Psi_{\mathrm{P}},(\sim 0 \mathrm{MPa})$. This led to foliar folding, which is a mechanism of resistance that minimizes water loss [66], and later the point of wilting with defoliation symptoms. With these disorders, gas exchange was severely reduced. Under the suppression of irrigation, the $\Psi_{1}$ values decreased much more in mandarin trees than in grapefruit trees (see Figure S2) due to mandarin plants generally having lower hydraulic conductance than grapefruit plants. Another study in two orange varieties found that the variety with reduced hydraulic conductivity presented more negative water potential and $g_{s}$ values under the same high evaporative demand period [44]. As for mandarin trees fully irrigated with saline RW (RW-fI), contrary to what was observed in grapefruit trees, the gas exchange was not reduced by water quality because the $\Psi_{\text {soil }}$, plant hydraulic conductance, and $\Psi_{1}$ were unaffected. In spite of the $\Psi_{\pi}$ decreasing slightly at some point, the high salinity in the leaves did not give rise to a specific ion effect, but could help to increase the leaf turgor versus control. Even though the $\Psi_{100 \mathrm{~s}}$ data did not indicate an important $\mathrm{OA}$ in this treatment, when the $\Psi_{\mathrm{P}}$ of citrus plants under saline conditions is similar to or higher than that of control trees, $\mathrm{Cl}^{-}$and $\mathrm{Na}^{+}$accumulation represent OA processes, according to [67]. Finally, contrary to what we hypothesized, the nI treatment preconditioned by salinity stress (RW-nI) maintained a better water status during drought stress, since the $\Psi_{\text {soil }}, K$, and $\Psi_{1}$ were reduced much by much less than in TW-nI. This was justified because the canopy volume of RW-nI was less than that of TW-nI. The

mboxemphCarrizo citrange (mandarin) rootstock was a less effective $\mathrm{Cl}^{-}$and $\mathrm{Na}^{+}$excluder under salinity conditions [60]; that is, mandarin trees did not develop a strategy for the removal of saline ions from the RW source as grapefruit trees did, but instead opted for an osmotic strategy involving the accumulation of leaf $\mathrm{Na}^{+}$and $\mathrm{Cl}^{-}$, affecting vegetative growth and yield [7]. Further, the RW-nI trees underwent acclimatization to salinity by reducing the drop in the water potential over several vegetative cycles for the same experimental plot, as reported in [68].

\subsection{Relationship between Water Relations and Hydraulic Conductance: Near-Isohidric or Anisohydric Behavior}

Citrus is considered isohydric in general, since it usually presents a stomatal sensitivity to water stress conditions [19]. In previous studies from the same experimental plots but with 
moderate deficit irrigation instead of total irrigation suppression $[5-7,36,42,68]$, there was not a complete prioritization of the stomatal aperture for maintenance of $\mathrm{CO}_{2}$ assimilation. Additionally, the $\Psi_{\mathrm{S}}$ values did not vary widely throughout several growth seasons for the same treatment nor between treatments, indicating a possible typical isohydric behavior. Nevertheless, it should be considered that there may be more than one definition of isohydricity and that the different definitions are not always in agreement [69]. Consistent with the concept presented in [70], here both citrus species displayed a stomatal sensitivity to soil water and evaporative demands, although to different degrees. Grapefruit trees showed higher reference $g_{s}\left(g_{s R e f}\right.$, corresponding to $g_{s}$ at $\left.1 \mathrm{kPa} V P D\right)\left(g_{s R e f}=0.092 \mathrm{~mol} \cdot \mathrm{m}^{-2} \cdot \mathrm{s}^{-1}\right)$ than mandarin $\left(g_{s R e f}=0.078 \mathrm{~mol} \cdot \mathrm{m}^{-2} \cdot \mathrm{s}^{-1}\right)$, suggesting that grapefruit trees tended to have a more sensitive response to increasing VPD (see slopes in Figure 4C,D). This lower stomatal sensitivity of mandarin to VPD and $\Psi_{\text {soil }}$ could indicate a less isohydric behavior compared to grapefruit, according to the theory presented in [11]. Nonetheless, greater $\mathrm{g}_{\mathrm{s}}$ regulation to prevent decreased water potential to levels that provoke excessive loss of hydraulic conductance was not possible due to the low gas exchange levels of mandarin trees, in accordance with [71]. The isohydric plant concept presented by [72] implies a similarity in midday $\Psi_{1}$ values in $\mathrm{nI}$ and fI plants. This did not occur here in mandarin crop, in which the $\Psi_{1}$ values varied by more than $1 \mathrm{MPa}$ among treatments (Figure 1B), indicating again that the mandarin crop had a near anisohydric response as compared to the grapefruit crop. The apparent simplicity of the concept could lead to misinterpretation of isohydry as a simple functional trait or a strategy defined by the isolated action of the stomata and not a response of the entire plant in order to regulate the water status [69]. In our study, when the isohydricity concept was assessed within a whole-plant perspective, we found that the strong stomatal control maintained relatively constant internal water potential gradients (hydrodynamic showed by $\left.\Delta \Psi_{\text {plant }}\right)$ in mandarin trees, while at the same time allowing $\Psi_{1}$ to fluctuate intensely on a diurnal basis in synchrony with $\Psi_{\text {soil }}$. This pattern of hydraulic regulation of mandarin trees was defined as isohydrodynamic by [73]. According to our knowledge, this is the first time that these species have been defined in the literature. As grapefruit is isohydric and mandarin is more anisohydric than grapefruit but also isodydrodynamic, mandarin plants did not prioritize stomatal opening, and for this reason mandarin did not neatly fit into the anisohydric extremes. Frameworks that mathematically link isohydricity and sensitivity to VPD have recently been developed [74], but they await empirical validation of stomatal sensitivity to VPD in diurnal environmental gradients [11]. The difference observed here among both citrus crops are in agreement with decades of studies that have highlighted the fact that stomatal sensitivity to VPD is highly variable across species [75-77]. Generally, we found an important decrease in $g_{s}$ with diurnally increasing VPD in all treatments, in agreement with other authors $[78,79]$, although when the whole growth season was evaluated, the VPD had less influence on $g_{s}$. Regarding the water stress, stomatal closure throughout the day was correlated with $\Psi_{1}$ in addition to VPD in grapefruits plants by not completely avoiding a decrease in $\Psi_{1}$, which also occurred to a lesser for mandarin plants. No consensus exists as to the exact sensing mechanisms driving the stomatal closure response to increased VPD [11]. Part of the uncertainty associated with the impacts of VPD on plants relates to the difficulty of disentangling the effects of VPD from those of $\mathrm{T}_{1}$ [80]. Additionally, few studies have documented the direct stomatal response to $T_{1}$ [81]. Here, $T_{1}$ had a positive effect on $\mathrm{g}_{\mathrm{s}}$ only with $\mathrm{T}_{1}<30{ }^{\circ} \mathrm{C}$, in accordance with [11], who reported that when VPD is low and stomata are fully open, $\mathrm{T}_{1}$ increases linearly with VPD.

Moreover, our findings regarding $\mathrm{K}$ highlighted the fundamental role of plant hydraulics in driving stomatal closure [51] in response to high VPD at midday and high soil water variation; that is, the $\mathrm{K}_{\text {root-stem }}$ (in both crops) and $\mathrm{K}_{\text {canopy }}$ (in mandarin) values were strongly related to $\mathrm{g}_{\mathrm{s}}$. So far, we have not found any studies on citrus trees with the rootstocks studied here, on irrigation with saline RW, or involving field trials. Nevertheless, other studies have reported results in the same direction as ours-reduced $\mathrm{K}$ at low water potential can enhance stomatal closure during drought [33], while at greater water stress levels, $\mathrm{K}_{\text {leaf }}$ [48] or $\mathrm{K}_{\text {plant }}$ [82] decreases with a concominant decline in $\mathrm{g}_{\mathrm{s}}$ [56]. Regarding 
salinity, decreased $\mathrm{K}_{\text {root }}$ caused by $\mathrm{NaCl}$ in sour orange and Cleopatra mandarin [83] and reductions in $\mathrm{K}_{\text {root }}$ of seedlings of Cleopatra mandarin, Carrizo citrange, and Poncirus trifoliara under long-term salt treatments have been reported [84].

The loss of hydraulic plant functioning has been considered one of the main driving factors of stomatal closure recently [15]. In grapefruit, the fact that midday $\mathrm{g}_{\mathrm{s}}$ was bettercorrelated with $\mathrm{K}_{\text {root-stem }}$ than with $\mathrm{K}_{\text {canopy }}$ suggested that $\mathrm{g}_{\mathrm{s}}$ reductions under water stress (nI treatments) happened in response to certain root- or stem-based signals, in line with [49]. Additionally, the sensitivity of $\mathrm{g}_{\mathrm{s}}$ to $\mathrm{K}_{\text {root-stem }}$ was 2.5 time higher in grapefruit than in mandarin, in which $\mathrm{g}_{\mathrm{s}}$ responded more sensitively to $\mathrm{K}_{\text {canopy }}$.

The other major mechanism considered to trigger stomatal closure is the increase in chemical signals such as ABA [85]. The water flow reduction through some parts of the roots, which might be hydraulically isolated due to severe water stress, could be related to a reduced release of root ABA into the leaf xylem [86]. This would explain why the lowest ABA values in our study were found with TW-nI treatment of mandarin; however, in recent experiments (although not in citrus) have shown strong stomatal responses to changes in water supply originating primarily in the leaves, but not in the roots $[87,88]$. Here, the fact that $g_{s}$ did not correlate with leaf ABA suggested that the importance of ABA in controlling $g_{s}$ had lower weight than hydraulic conductance. Other authors also found that the relationship of ABA with $g_{s}$ was not significant under drought conditions in olive plants [48] and in almond, grapevine, and olive crops [33].

\section{Materials and Methods}

\subsection{Experimental Conditions and Plant Materials}

The experiment was conducted on a commercial citrus orchard, located in the northeast of the Murcia region in Campotéjar, $7 \mathrm{~km}$ north of Molina de Segura $\left(38^{\circ} 07^{\prime} 18^{\prime \prime} \mathrm{N}\right.$, $\left.1^{\circ} 13^{\prime} 15^{\prime \prime} \mathrm{W}\right)$. There were two experimental plots measuring 0.5 ha each. The first was cultivated with adult 8 year-old Star Ruby grapefruit trees (Citrus paradisi Macf) grafted on Macrophylla (Citrus macrophylla) rootstock and planted at $6 \times 4 \mathrm{~m}$. The second plot contained adult 14-year-old mandarin trees (Citrus clementina cv. 'Orogrande') grafted on Carrizo citrange (Citrus sinensis (L.) Osb. $\times$ Poncirus trifoliata (L.)) rootstock and planted at $5 \times 3.5 \mathrm{~m}$.

The irrigation was scheduled on the basis of daily evapotranspiration of the crop $\left(\mathrm{ET}_{\mathrm{c}}\right)$ accumulated during the previous week. $\mathrm{ET}_{\mathrm{c}}$ values were estimated as reference evapotranspiration $\left(\mathrm{ET}_{0}\right)$ values, calculated with the Penman-Monteith methodology and a monthly local crop factor [89]. All treatments included application of the same amounts of fertilizer $\left(\mathrm{N}-\mathrm{P}_{2} \mathrm{O}_{5}-\mathrm{K}_{2} \mathrm{O}\right)$ applied through the drip irrigation system (see [90]). Weeds were eradicated in the orchard by applying the farmers' commonly used pest control methods [63].

\subsection{Water Sources and Irrigation Treatments}

The experimental plot of grapefruit and mandarin plants was irrigated with two water sources of different quality over six years of cultivation. The first type of irrigation water was pumped from the Tajo-Segura canal (transfer water, TW), while the second water source came from the north of "Molina de Segura" tertiary wastewater treatment plant (WWTP) (reclaimed water, RW). The latter source was characterized by having high salt and electrical conductivity (EC) values close to $4 \mathrm{dS} \cdot \mathrm{m}^{-1}$, while for TW the EC values were lower at close to $1 \mathrm{dS} \cdot \mathrm{m}^{-1}$ (annual average value: $0.93 \pm 0.14 \mathrm{dS} \cdot \mathrm{m}^{-1}$ ). The saline water source was automatically blended in the irrigation control head with water from TW to reduce its EC value to approximately $3.5 \mathrm{dS} \cdot \mathrm{m}^{-1}$ (annual average value: $\left.3.73 \pm 0.80 \mathrm{dS} \cdot \mathrm{m}^{-1}\right)$, as an intermediate value between the threshold for significant yield losses $\left(1.5-2 \mathrm{dS} \cdot \mathrm{m}^{-1}\right)$ [91] and the average EC of $4 \mathrm{dS} \cdot \mathrm{m}^{-1}$ at the outlet of the WWTP. This high level of salinity observed in RW was mainly due to the high concentrations of $\mathrm{Cl}^{-}\left(69.95 \pm 22.04\right.$ and $639.31 \pm 189.91 \mathrm{mg} \mathrm{L}^{-1}$ for TW and RW, respectively) and Na+ (46.03 \pm 14.18 and $604.03 \pm 121.65 \mathrm{mg} \mathrm{L}^{-1}$ for TW and RW, respectively) (see Table S1). 
Two irrigation treatments were applied for each water source and crop. The first was the fully irrigated treatment (fI), with irrigation occurring throughout the growing season to fully satisfy the crops' water requirements $\left(100 \%\right.$ of crop evapotranspiration, $\mathrm{ET}_{\mathrm{C}}$ ). The, second, was the non-irrigated treatment (nI), with an irrigation regime similar to fI, except for a two month period during one growing season (from 214 to 274 DOY; that is, from 1st August to 1st October) in which trees were not irrigated $\left(0 \% \mathrm{ET}_{\mathrm{c}}\right)$. This period of total suppression of irrigation was selected, taking into account the months of high evaporative demands that allowed the plants to reach a state of high stress; therefore, four treatments (TW-fI, TW-nI, RW-fI, and RW-nI) were established for each crop (grapefruit and mandarin). TW-fI was considered as the control treatment in both crops. The annual amounts of water applied for grapefruit and mandarin trees were 5700 and $7940 \mathrm{~m}^{3} \cdot \mathrm{ha}^{-1}$, respectively, for the fI treatments; and 4618 and $6375 \mathrm{~m}^{3} \cdot \mathrm{ha}^{-1}$, respectively, for nI treatments.

\subsection{Measurements}

Physiological plant measurements were carried out periodically from 213 to 283 DOY (i.e., before the beginning of the total irrigation suppression period and until 9 days after the end) (Figure S1). When severe water stress was reached using some of the nI treatments, a diurnal evolution was performed (248 DOY, 34 days after the initiation of total irrigation suppression).

\subsubsection{Plant Water Status}

Stomatal conductance $\left(\mathrm{g}_{\mathrm{s}}\right)$, leaf temperature $\left(\mathrm{T}_{1}\right)$, vapor pressure deficit based on leaf temperature (VPD), stem water potential $\left(\Psi_{S}\right)$, leaf water potential $\left(\Psi_{1}\right)$, leaf osmotic potential $\left(\Psi_{\pi}\right)$, and leaf osmotic potential at full turgor $\left(\Psi_{100 \mathrm{~s}}\right)$ were determined on one mature leaf, which was fully expanded from the mid-shoot area of each tree. Here, $\Psi_{1}$ was measured at predawn and was used as an estimate of soil water potential $\left(\Psi_{\text {soil }}\right)$.

The $g_{s}, T_{1}$, and VPD were measured with a portable photosynthesis system (LI-6400 Li-Cor, Lincoln, Nebraska, USA) equipped with a clear chamber bottom (6400-08) and a LICOR 6400-01 $\mathrm{CO}_{2}$ injector. The measurements were performed on leaves that were placed in a $6 \mathrm{~cm}^{2}$ leaf cuvette. The $\mathrm{CO}_{2}$ concentration in the cuvette was maintained at $400 \mu \mathrm{mol} \cdot \mathrm{mol}^{-1}$ ( $\approx$ ambient $\mathrm{CO}_{2}$ concentration). The measurements were carried out at ambient air temperature and relative humidity. Measurements were taken approximately every hour on the same leaf from 06.00 to 19.00 GMT.

The $\Psi_{\mathrm{S}}$ and $\Psi_{1}$ were measured in a single mature leaf from the same region of the canopy using a Scholander-type pressure chamber (model 3000; Soil Moisture Equipment Corp.; Santa Barbara, California, US; [92]) and following the recommendations in [93]. The $\Psi_{\mathrm{s}}$ was measured at midday and the leaves were covered with aluminum foil and enclosed within polyethylene bags at least $2 \mathrm{~h}$ before collection and measurement [94]. The $\Psi_{1}$ was measured periodically throughout the day. The leaves used to measure $\Psi_{1}$ at predawn and at midday were frozen in liquid $\mathrm{N}\left(-196^{\circ} \mathrm{C}\right)$ and stored at $-30^{\circ} \mathrm{C}$. After thawing, $\Psi_{\pi}$ was measured in the extracted sap using a WESCOR 5520 vapor pressure osmometer (Wescor Inc.; Logan, UT, US) according to [95]. The pressure potential ( $\Psi_{\mathrm{P}}$ ) was calculated as the difference between $\Psi_{1}$ and $\Psi_{\pi}$. The leaf osmotic potential at full turgor $\left(\Psi_{100 s}\right)$ was estimated at midday as indicated above for $\Psi_{\pi}$, using excised leaves with their petioles placed in distilled water overnight to reach full saturation. The osmotic adjustment (OA) was calculated as the difference in $\Psi_{100 \text { s }}$ between the control (TW-fI) and the rest of the treatments.

The canopy hydraulic conductance ( $\left.\mathrm{K}_{\text {canopy }}\right)$ and root-stem conductance $\left(\mathrm{K}_{\text {root-stem }}\right)$ were estimated using the evaporative flux method [96]. On the one hand, the $\mathrm{K}_{\text {canopy }}$ was calculated under steady-state conditions according to Ohm's law,

$$
\mathrm{K}_{\text {canopy }}=\mathrm{T}_{\mathrm{r}} / \text { Midday } \Delta \Psi_{\text {stem-leaf }}
$$


where Midday $\Delta \Psi_{\text {stem-leaf }}$ is the water potential drop (MPa) across the stem-leaf pathway, obtained as the difference between $\Psi_{\mathrm{S}}$ and $\Psi_{1}$, both at midday. On the other hand, $\mathrm{K}_{\text {root-stem }}$ was also calculated according to Ohm's law,

$$
\mathrm{K}_{\text {canopy }}=\mathrm{T}_{\mathrm{r}} / \text { Midday } \Delta \Psi_{\text {stem-leaf }}
$$

where Midday $\Delta \Psi_{\text {root-stem }}$ is the water potential drop (MPa) across the root-stem pathway obtained as the difference between predawn $\Psi_{1}$ and midday $\Psi_{\mathrm{S}}$. The hydrodynamic (transpiration-induced) water potential gradient from roots to shoots $\left(\Delta \Psi_{\text {plant }}\right)$ was calculated as the difference between predawn and midday $\Psi_{1}$.

\subsubsection{Leaf Chemical Analysis}

Leaf abscisic acid (ABA) and phytotoxic elements such as $\mathrm{Na}^{+}$and $\mathrm{Cl}^{-}$were determined on twenty mature leaves, which were fully expanded from the mid-shoot area in each tree. Leaf samples used to measure ABA concentrations were freeze-dried and finely ground. Deionized water was added at a 1:50 weight ratio. Samples extracts were analyzed using a radioimmunoassay [97] to obtain leaf ABA contents. The phytotoxic elements were determined as in [6].

\subsection{Statistical Design and Analysis}

The experimental design for each irrigation treatment involved 4 standard experimental plots distributed following a completely randomized design. Each replicate was made up of 12 trees, organized in 3 adjacent rows. A total of 192 grapefruit trees and 192 mandarin trees were used. All measurements were carried out in the two central trees of the middle row of each replicate ( 2 trees per block, 8 per treatment), while border trees were excluded from the study to eliminate potential edge effects.

The average values of each treatment were analyzed as assessed using Tukey's test. The significance of determination coefficients $\left(\mathrm{r}^{2}\right)$ from linear regression equations were indicated as Pearson correlation coefficients $(\mathrm{R})$. The data were also analyzed with a twoway ANOVA for repeated measures to examine the interaction between the treatments and time samplings. Further, the data were analyzed using a two-way ANOVA with the quality and amount of water as the main factors. These statistical analyses were performed with IBM SPSS Statistics software (version 23.0 for Windows, SPSS Inc.; Chicago, IL, USA).

\section{Conclusions}

Water and saline stresses triggered physiological changes in citrus trees in response to increases in VPD and soil drought throughout the day. Nonetheless, the degree of affectation and the strategies were differently modulated depending on the particular stress tolerance of the citrus crop and rootstock. In grapefruit, the use of RW and the irrigation suppression negatively affected the plant physiology, with the treatment that combined both stresses (RW-nI) being the one that most affected water status. In mandarin, the trees under saline stress (RW-fI) accumulated salts, unlike grapefruit, as an osmotic strategy. Then, the leaf turgor improved and the gas exchange was maintained similarly to control. The treatment that most affected water status was not RW-nI, as we expected, but TW-nI. This treatment presented injury symptoms, similarly to senescence, which were the consequence of the depletion of soil water and a critical drop in the $\Psi_{1}$ that led to a severe loss of K. Such behavior was not observed with RW-nI because a slight reduction in the canopy volume as an adaptive characteristic was found, suggesting that when mandarin trees under water stress were previously acclimated to saline stress they were more effective in avoiding harmful cavitation. Thus, from a physiological point of view (without taking into account fruit yield), mandarin trees tolerated drought less than grapefruit trees, mainly because of their low K levels. Additionally, the mandarin crop exhibited more anisohydric behavior compared with the grapefruit crop due to the noteworthy drop of $\Psi_{1}$ under water stress. Nevertheless, from a whole-plant perspective $\left(\Delta \Psi_{\text {plant }}\right)$, a constant hydrodynamic pattern more typical of isohydric crops was found 
in mandarin, defining it as isohydrodynamic. Moreover, grapefruit showed an isohydric pattern that limited the use of $\Psi_{1}$ as an indicator of plant water status. Here, the $g_{s}$ did show as a good water status indicator for irrigation scheduling purposes and was negatively correlated with the hourly increase in VPD for both crops. Our ABA data added to a growing body of evidence challenging the ABA-centric model of stomatal responses to abiotic stress, with $\mathrm{K}$ being the key factor. Further studies focusing on leaf hydraulic conductivity are required to understand the role of hydraulics and its mechanism on stomatal regulation in citrus.

Supplementary Materials: The following are available online at https://www.mdpi.com/article/10 .3390 / plants10102121/s1, Figure S1: Annual data for rainfall, reference evapotranspiration $\left(\mathrm{ET}_{0}\right)$, and vapor pressure deficit based on the air temperature $\left(\mathrm{VPD}_{\text {air }}\right)$; Figure S2: Relation between leaf water potential $\left(\Psi_{1}\right)$ and vapor pressure deficit (VPD) for each treatment; Figure S3. Relationship between vapor pressure deficit (VPD) and leaf temperature $\left(\mathrm{T}_{1}\right)$ for each crop (grapefruit and mandarin); Table S1: Chemical parameters of each irrigation water source: Transfer Water (TW) and saline Reclaimed Water (RW).

Author Contributions: Conceptualization, C.R.-T. and E.N.N.; methodology, C.R.-T., E.N.N., P.A.N.T., and J.M.B.G.; software, C.R.-T. and E.N.N.; validation, C.R.-T. and P.A.N.T.; formal analysis, C.R.-T.; investigation, E.N.N., P.A.N.T., J.J.A.C., and C.R.-T.; resources, E.N.N. and J.J.A.C.; data curation, C.R.-T. and J.M.B.G.; writing—original draft preparation, C.R.-T.; writing—review and editing, E.N.N. and C.R.-T.; visualization, E.N.N. and C.R.-T.; supervision, E.N.N.; project administration, E.N.N.; funding acquisition, E.N.N. All authors have read and agreed to the published version of the manuscript.

Funding: This research was funded by Spanish Ministry projects with European Union FEDER funds (CICYT (FEDER, UE, AGL2010-17553; FEDER, UE, AGL2013-49047-C2-2-R; AEI/FEDER, UE, AGL2016-77282-C3-1- R; PID2019-106226RB-C21/ AEI/10.13039/501100011033)) granted to the authors.

Data Availability Statement: Data is contained within the article and Supplementary Materials.

Acknowledgments: C. Romero-Trigueros acknowledges the financial support of the Consejería de Empleo, Universidades y Empresa (CARM), through the Fundación Séneca-Agencia de Ciencia y Tecnología de la Región de Murcia, for a postdoctoral fellowship (20363/PD/17), as well as the Spanish Research Agency of the Ministry of Science and Innovation for a contract from Juan de la Cierva-Incorporación (JC2019-040871-I). The authors are also grateful to the Fundación Séneca $(19903 /$ GERM/15)

Conflicts of Interest: The authors declare no conflict of interest.

\section{References}

1. Jamshidi, S.; Zand-Parsa, S.; Niyogi, D. Assessing crop water stress index of citrus using in-situ measurements, landsat, and sentinel-2 data. Int. J. Remote Sens. 2021, 42, 1893-1916. [CrossRef]

2. Romero-Trigueros, C.; Alarcón, J.J.; Nortes, P.A.; Bayona, J.M.; Maestre-Valero, J.; Nicolás, E. Mid-long term effects of saline reclaimed water irrigation and regulated deficit irrigation on fruit quality of citrus. J. Sci. Food Agric. 2020, 100, 1350-1357. [CrossRef]

3. Li, X.; Li, X.; Li, Y. Research on reclaimed water from the past to the future: A review. Environ. Develop. Sustain. 2021. [CrossRef]

4. Romero-Trigueros, C.; Nortes, P.A.; Alarcón, J.J.; Nicolás, E. Determination of $15 \mathrm{~N}$ stable isotope natural abundances for assessing the use of saline reclaimed water in grapefruit. Environ. Eng. Manag. J. 2014, 13, 2525-2530. [CrossRef]

5. Romero-Trigueros, C.; Nortes, P.A.; Pedrero, F.; Mounzer, M.; Alarcón, J.J.; Bayona, J.M.; Nicolás, E. Assessment of the viability of using saline reclaimed water in grapefruit in medium to long term. Span. J. Agric. Res. 2014, 12, 1137-1148. [CrossRef]

6. Romero-Trigueros, C.; Nortes, P.; Alarcón, J.J.; Hunink, J.E.; Parra, M.; Contreras, S.; Droogers, P.; Nicolás, E. Effects of saline reclaimed waters and deficit irrigation on Citrus physiology assessed by UAV remote sensing. Agric. Water Manag. 2017, 183, 60-69. [CrossRef]

7. Nicolás, E.; Romero-Trigueros, C.; Nortes, P.A.; Pedrero, F.; Bayona, J.M.; Maestre-Valero, J.F.; Alarcón, J.J. Chapter 7: Long-term physiological and agronomic responses of citrus irrigated with saline reclaimed water. In Water Scarcity and Sustainable Agriculture in Semiarid Environment; Academic Press: Cambridge, MA, USA, 2018; pp. 131-147. ISBN 978-0-12-813164-0. [CrossRef]

8. Grattan, S. Evaluation of the Impact of Boron on Citrus Orchards in Riverside Country; Riverside County Water Task Force: Riverside, CA, USA, 2013; 78p. 
9. García-Sánchez, F.; Syvertsen, J.P.; Gimeno, V.; Botia, P.; Pérez-Pérez, J.G. Responses to flooding and drought stress by two citrus rootstock seedlings with different water-use efficiency. Physiol. Plant 2007, 130, 532-542. [CrossRef]

10. Pantin, F.; Monnet, F.; Jannaud, D.; Costa, J.M.; Renaud, J.; Muller, B.; Simonneau, T.; Genty, B. The dual effect of abscisic acid on stomata. New Phytol. 2013, 97, 65-72. [CrossRef] [PubMed]

11. Grossiord, C.; Buckley, T.N.; Cernusaket, L.A.; Novick, K.A.; Poulter, B.; Siegwolf, R.T.W.; Sperry, J.S.; McDowell, N.G. Plant responses to rising vapor pressure deficit. New Phytol. 2020, 226, 1550-1566. [CrossRef]

12. Pou, A.; Medrano, H.; Magdalena, T. Anisohydric behaviour in grapevines results in better performance under moderate water stress and recovery than isohydric behaviour. Plant Soil 2012, 359, 335-349. [CrossRef]

13. Dal Santo, S.; Palliotti, A.; Zenoni, S.; Tornielli, G.B.; Fasoli, M.; Paci, P.; Tombesi, S.; Frioni, T.; Silvestroni, O.; Bellincontro, A.; et al. Distinct transcriptome responses to water limitation in isohydric and anisohydric grapevine cultivars. BMC Genom. 2016, 17, 815. [CrossRef]

14. Hartmann, H.; Mathias, F.; Schuldt, B. A whole-plant perspective of isohydry: Stem-level support for leaf-level plant water regulation. Tree Physiol. 2021, 41, 901-905. [CrossRef] [PubMed]

15. Rodríguez-Domínguez, C.M.; Brodribb, T.J. Declining root water transport drives stomatal closure in olive under moderate water stress. New Phytol. 2020, 225, 126-134. [CrossRef] [PubMed]

16. Yang, Y.J.; Bi, M.H.; Nie, Z.F.; Jiang, H.; Liu, X.D.; Fang, X.W.; Brodribb, T.J. Evolution of stomatal closure to optimize water-use efficiency in response to dehydration in ferns and seed plants. New Phytol. 2021, 230, 2001-2010. [CrossRef] [PubMed]

17. Hochberg, U.; Degu, A.; Fait, A.; Rachmilevitch, S. Near isohydric grapevine cultivar displays higher photosynthetic efficiency and photorespiration rates under drought stress as compared with near anisohydric grapevine cultivar. Physiol. Plant. 2013, 147, 443-452. [CrossRef] [PubMed]

18. Meinzer, F.C.; Smith, D.D.; Woodruff, D.R.; Marias, D.E.; MacCulloh, K.A.; Howard, A.R.; Magedman, A.L. Stomatal kinetics and photosynthetic gas exchange along a continuum of isohydric to anisohydric regulation of plant water status. Plant Cell Environ. 2017, 40, 1618-1628. [CrossRef]

19. Mira-García, A.B. Evaluation of Physiological Indicators of Water Stress in Verna Lemon Tree. Master's Thesis, Orihuela Higher Polytechnic School, Miguel Hernández University of Elche, Elche, Spain, 2016.

20. Banuls, J.; Serna, M.D.; Legaz, F.; Talon, M.; Primo-Millo, E. Growth and gas exchange parameters of Citrus plants stressed with different salts. J. Plant Physiol. 1997, 150, 194-199. [CrossRef]

21. Vivaldi, A.G.; Lopriore, G.; Romero-Trigueros, C.; Pedrero, F.; Camposeo, S.; Álvarez, S. Physiological responses of almond trees under regulated deficit irrigation using saline and desalinated reclaimed water. Agric. Water Manag. 2021. accepted.

22. McAdam, S.A.M.; Brodribb, T.J. Linking turgor with ABA biosynthesis: Implications for stomatal responses to vapour pressure deficit across land plants. Plant Physiol. 2016, 171, 00380. [CrossRef]

23. Dodd, I.C. Abscisic acid and stomatal closure: A hydraulic conductance conundrum? New Phytol. 2013, 197, 6-8. [CrossRef]

24. Shang, Y.; Yang, D.; Ha, Y.; Lee, J.Y.; Kim, J.Y.; Oh, M.; Nam, K.H. Open stomata 1 exhibits dual serine/threonine and tyrosine kinase activity in regulating abscisic acid signaling. J. Exp. Bot. 2021, 72, 5494-5507. [CrossRef] [PubMed]

25. Christmann, A.A.; Hoffmann, T.; Teplova, I.; Grill, E.; Muller, A. Generation of active pools of abscisic acid revealed by in vivo Imaging of water-stressed Arabidopsis. Plant Physiol. 2005, 137, 209-219. [CrossRef]

26. Israelsson, M.; Siegel, R.S.; Young, J.; Hashimoto, M.; Iba, K.; Schroeder, J.I. Guard cell ABA and $\mathrm{CO}_{2}$ signaling network updates and Ca2+ sensor priming hypothesis. Curr. Opin. Plant Biol. 2006, 9, 654-663. [CrossRef]

27. Reynolds-Henne, C.E.; Langenegger, A.; Mani, J.; Schenk, N.; Zumsteg, A.; Feller, U. Interactions between temperature, drought and stomatal opening in legumes. Environ. Exp. Bot. 2010, 68, 37-43. [CrossRef]

28. Brodribb, T.J.; Holbrook, N.M. Diurnal depression of leaf hydraulic conductance in a tropical tree species. Plant Cell Environ. 2004, 27, 820-827. [CrossRef]

29. Christmann, A.A.; Weiler, E.W.; Steudle, E.; Grill, E. Hydraulic signal in root-to-shoot signalling of water shortage. Plant J. 2007, 52, 167-174. [CrossRef]

30. Saliendra, N.Z.; Sperry, J.S.; Comstock, J.P. Influence of leaf water status on stomatal response to humidity, hydraulic conductance, and soil drought in Betula-occidentalis. Planta 1995, 196, 357-366. [CrossRef]

31. Mrad, A.; Sevanto, S.; Domec, J.-C.; Liu, Y.; Nakad, M.; Katul, G. A Dynamic Optimality Principle for Water Use Strategies Explains Isohydric to Anisohydric Plant Responses to Drought. Front. For. Glob. Change 2019, 2, 49. [CrossRef]

32. Sperry, J.S.; Hacke, U.G.; Oren, R.; Comstock, J.P. Water deficit and hydraulic limits to leaf water supply. Plant Cell Environ. 2002, 25, 251-263. [CrossRef] [PubMed]

33. Rodriguez-Dominguez, C.M.; Buckley, T.N.; Egea, G.; de Cires, A.; Hernandez-Santana, V.; Martorell, S.; Diaz-Espejo, A. Most stomatal closure in woody species under moderate drought can be explained by stomatal responses to leaf turgor. Plant Cell Environ. 2016, 39, 2014-2026. [CrossRef] [PubMed]

34. Buckley, T.N. How do stomata respond to water status? New Phytol. 2019, 224, 21-36. [CrossRef]

35. Garcia-Tejero, I.; Jimenez-Bocanegra, J.A.; Martinez, G.; Romero, R.; Duran-Zuazo, V.H.; Muriel-Fernandez, J. Positive impact of regulated deficit irrigation on yield and fruit quality in a commercial citrus orchard [Citrus sinensis (L.) Osbeck, cv. salustiano]. Agric. Water Manag. 2010, 97, 614-622. [CrossRef]

36. Romero-Trigueros, C.; Bayona, J.M.; Nortes, P.; Alarcón, J.J.; Nicolás, E. Determination of crop water stress index by thermometry in grapefruit trees irrigated with saline reclaimed water combined with deficit irrigation. Remote Sens. 2019, 11, 757. [CrossRef] 
37. Sampaio, A.H.R.; Silva, R.O.; Brito, R.B.F.; Soares, W.D.; Gesteira, A.D.; Souza, L.D.; Coelho, M.A. Sweet orange acclimatisation to water stress: A rootstock dependency. Sci. Hortic. 2021, 276, 109727. [CrossRef]

38. Rodríguez-Gamir, J.; Intrigliolo, D.S.; Primo-Millo, E.; Forner-Giner, M.A. Relationships between xylem anatomy, root hydraulic conductivity, leaf/root ratio and transpiration rates in citrus trees on different rootstocks. Physiol. Plant. 2010, 139, 159-169. [CrossRef] [PubMed]

39. Gimeno, V.; Syvertsen, J.P.; Simon, I.; Martinez, V.; Camara-Zapata, J.M.; Nieves, M.; Garcia-Sanchez, F. Interstock of ‘Valencia' Orange Affects the Flooding Tolerance in 'Verna' Lemon Trees. Hortscience 2012, 47, 403-409. [CrossRef]

40. Xiong, D.L.; Flexas, J. From one side to two sides: The effects of stomatal distribution on photosynthesis. New Phytol. 2020, 228, 1754-1766. [CrossRef]

41. Rodríguez-Dominguez, C.M.; Hernández-Santana, V.; Buckley, T.N.; Fernández, J.E.; Díaz-Espejo, A. Sensitivity of olive leaf turgor to air vapour pressure deficit correlates with diurnal maximum stomatal conductance. Agric. For. Meteorol. 2019, 272-273, 156-165. [CrossRef]

42. Pedrero, F.; Maestre-Valero, J.F.; Mounzer, O.; Nortes, P.A.; Alcobendas, R.; Romero-Trigueros, C.; Bayona, J.M.; Alarcón, J.J.; Nicolás, E. Response of young 'Star Ruby' grapefruit trees to regulated deficit irrigation with saline reclaimed wáter. Agric. Water Manag. 2015, 158, 51-60. [CrossRef]

43. Nicolas, E.; Alarcón, J.J.; Mounzer, O.; Pedrero, F.; Nortes, P.A.; Alcobendas, R.; Romero-Trigueros, C.; Bayona, J.M.; MaestreValero, J.F. Long-term physiological and agronomic responses of mandarin trees to irrigation with saline reclaimed water. Agric. Water Manag. 2016, 166, 1-8. [CrossRef]

44. Syvertsen, J.P.; Graham, J.H. Hydraulic conductivity of roots, mineral nutrition, and leaf gas exchange of Citrus rootstocks. J. Am. Soc. Hortic. Sci. 1985, 110, 865-869.

45. Forner-Giner, M.A.; Rodriguez-Gamir, J.; Primo-Millo, E. Hydraulic and Chemical Responses of Citrus Seedlings to Drought and Osmotic Stress. J. Plant Growth Regul. 2011, 30, 353-366. [CrossRef]

46. Martínez-Alcántara, B.; Rodríguez-Gamir, J.; Martínez-Cuenca, M.R.; Iglesias, D.J.; Primo-Millo, E.; Forner-Giner, M.A. Relationship between hydraulic conductance and citrus dwarfing by the Flying Dragon rootstock (Poncirus trifoliata L. Raft var. Monstrosa). Trees 2013, 27, 629-638. [CrossRef]

47. Flexas, J.; Bota, J.; Loreto, F.; Cornic, G.; Sharkey, T.D. Diffusive and metabolic limitations to photosynthesis under drought and salinity in C3 plants. Plant Biol. 2004, 6, 269-279. [CrossRef] [PubMed]

48. Hernández-Santana, V.; Rodríguez-Domínguez, C.; Fernández, J.E.; Espejo-Díaz, A. Role of leaf hydraulic conductance in the regulation of stomatal conductance in almond and olive in response to water stress. Tree Physiol. 2016, 36, 725-735. [CrossRef] [PubMed]

49. Froux, F.; Ducrey, M.; Dreyer, E.; Huc, R. Vulnerability to embolism differs in roots and shoots and among three Mediterranean conifers: Consequences for stomatal regulation of water loss? Trees 2005, 19, 137-144. [CrossRef]

50. Grassi, G.; Ripullone, F.; Borghetti, M.; Raddi, S.; Magnani, F. Contribution of diffusional and non-diffusional limitations to midday depression of photosynthesis in Arbutus unedo L. Trees 2009, 23, 1149-1161. [CrossRef]

51. Zhang, Y.J.; Meinzer, F.C.; Qi, J.H.; Goldstein, G.; Cao, K.F. Midday stomatal conductance is more related to stem rather than leaf water status in subtropical deciduous and evergreen broadleaf trees. Plant Cell Environ. 2013, 36, 149-158. [CrossRef]

52. Brodribb, T.J.; Jordan, G.J. Internal coordination between hydraulics and stomatal control in leaves. Plant Cell Environ. 2008, 31, 1557-1564. [CrossRef]

53. Flexas, J.; Ribas-Carbo, M.; Diaz-Espejo, A.; Galmes, J.; Medrano, H. Mesophyll conductance to $\mathrm{CO}_{2}$ : Current knowledge and future prospects. Plant Cell Environ. 2008, 31, 602-621. [CrossRef]

54. Schultz, H.R. Differences in hydraulic architecture account for near-isohydric and anisohydric behaviour of two field-grown Vitis vinifera L. cultivars during drought. Plant Cell Environ. 2003, 26, 1393-1405. [CrossRef]

55. Mounzer, O.; Pedrero, F.; Nortes, P.A.; Bayona, J.M.; Nicolás, E.; Alarcón, J.J. Transient soil salinity under the combined effect of reclaimed water and regulated deficit drip irrigation of Mandarin trees. Agric. Water Manage. 2013, 120, 23-29. [CrossRef]

56. Corso, D.; Delzon, S.; Lamarque, L.J.; Cochard, H.; Torres-Ruiz, J.M.; King, A.; Brodribb, T. Neither xylem collapse, cavitation, or changing leaf conductance drive stomatal closure in wheat. Plant Cell Environ. 2020, 43, 854-865. [CrossRef]

57. Girona, J.; Mata, M.; del Campo, J.; Arbonés, A.; Bartra, E.; Marsal, J. The use of midday leaf water potential for scheduling deficit irrigation in vineyards. Irrig. Sci. 2006, 24, 115-127. [CrossRef]

58. Mirás-Ávalos, J.M.; Pérez-Sarmiento, F.; Alcobendas, R.; Alarcón, J.J.; Mounzer, O.; Nicolás, E. Using midday stem water potential for scheduling deficit irrigation in mid-late maturing peach trees under Mediterranean conditions. Irrig. Sci. 2016, 34, 161-173. [CrossRef]

59. Brodribb, T.J.; McAdam, S.A.M. Evolution of the Stomatal Regulation of Plant Water Content. Plant Physiol. 2017, 174, 639-649. [CrossRef]

60. Navarro, J.M.; Garcia-Olmos, B.; Andujar, S.; Rodríguez-Morán, M.; Moreno, M.; Porras, I. Effects of calcium on growth and nutritional state of citrus seedlings under $\mathrm{NaCl}$ stress. In Proceedings of the 28th International Horticultural Congress on Science and Horticulture for People (IHC)/International Symposium on Climwater-Horticultural Use of Water in a Changing Climate, Lisbon, Portugal, 22-27 August 2010; Volume 922, pp. 55-60.

61. Chapman, H.D.; Reuther, W.; Batchelor, L.D.; Weber, H.J. The mineral nutrition of citrus. In The Citrus Industry; Reuther, W., Ed.; University of California: Berkeley, CA, USA, 1968; Volume 2, pp. 127-289. 
62. Levy, Y.; Shamhevet, J. Ranking the tolerance of citrus rootstocks by juice analysis. Sci. Hortic. 1990, 45, 89-98. [CrossRef]

63. Romero-Trigueros, C.; Parra, M.; Bayona, J.M.; Nortes, P.; Alarcón, J.J.; Nicolás, E. Effect of deficit irrigation and reclaimed water on yield and quality of grapefruits at harvest and postharvest. LWT Food Sci. Technol. 2017, 85, 405-411. [CrossRef]

64. Yahmed, B.J.; Novillo, P.; Garcia-Lor, A.; Salvador, A.; Ben Mimoun, M.; Luro, F.; Talon, M.; Ollitrault, P.; Morillon, R. Salt tolerance traits revealed in mandarins (Citrus reticulata Blanco) are mainly related to root-to-shoot $\mathrm{Cl}-$ translocation limitation and leaf detoxification processes. Sci. Hortic. 2015, 191, 90-100. [CrossRef]

65. Patakas, A.; Noitsakis, B. Cell wall elasticity as a mechanism to maintain favourable water relations during leaf ontogeny in grapevines. Am. J. Enol. Vitic. 1997, 48, 352-356.

66. Ocheltree, T.W.; Nippert, J.B.; Prasad, P.V.V. Stomatal sensitivity of C3 and C4 grasses. Plant Cell Environ. 2014, 37, 132-139. [CrossRef]

67. Pérez-Pérez, J.G.; Syvertsen, J.P.; Botia, P.; Garcia-Sanchez, F. Leaf water relations and net gas exchange responses of salinized Carrizo citrange seedlings during drought stress and recovery. Ann. Bot. 2007, 100, 335-345. [CrossRef]

68. Pedrero, F.; Maestre-Valero, J.F.; Mounzer, O.; Alarcón, J.J.; Nicolás, E. Physiological and agronomic mandarin trees performance under saline reclaimed water combined with regulated deficit irrigation. Agric. Water Manag. 2014, 146, 228-237. [CrossRef]

69. Hochberg, U.; Rockwell, F.E.; Holbrook, N.M.; Cochard, H. Iso/Anisohydry: A Plant-Environment Interaction Rather Than a Simple Hydraulic Trait. Trends Plant Sci. 2018, 23(2), 112-120. [CrossRef] [PubMed]

70. Oren, R.; Sperry, J.S.; Katul, G.G.; Pataki, D.E.; Ewers, B.E.; Phillips, N.; Schafer, K.V.R. Survey and synthesis of intra-and interspecific variation in stomatal sensitivity to vapour pressure deficit. Plant Cell Environ. 1999, 22, 1515-1526. [CrossRef]

71. Vogt, U.K. Hydraulic vulnerability, vessel refilling, and seasonal courses of stem water potential of Sorbus aucuparia L. and Sambucus nigra L. J. Exp. Bot. 2001, 52, 1527-1536. [CrossRef] [PubMed]

72. Tardieu, F.; Simonneau, T. Variability among species of stomatal control under fluctuating soil water status and evaporative demand: Modelling isohydric and anisohydric behaviours. J. Exp. Bot. 1998, 49, 419-432. [CrossRef]

73. Franks, P.J.; Drake, P.L.; Froend, R.H. Anisohydric but isohydrodynamic: Seasonally constant plant water potential gradient explained by a stomatal control mechanism incorporating variable plant hydraulic conductance. Plant Cell Environ. 2007, 30, 19-30. [CrossRef] [PubMed]

74. Novick, K.A.; Konings, A.G.; Gentine, P. Beyond soil water potential: An expanded view on isohydricity including landatmosphere interactions and phenology. Plant Cell Environ. 2019, 42, 1802-1815. [CrossRef]

75. Cunningham, S.C. Photosynthetic responses to vapour pressure deficit in temperate and tropical evergreen rainforest trees of Australia. Oecologia 2005, 142, 521-528. [CrossRef]

76. Creese, C.; Oberbauer, S.; Rundel, P.; Sack, L. Are fern stomatal responses to different stimuli coordinated? Testing responses to light, vapor pressure deficit, and $\mathrm{CO}_{2}$ for diverse species grown under contrasting irradiances. New Phytol. 2014, 204, 92-104. [CrossRef]

77. Gao, J.; Zhao, P.; Shen, W.; Niu, J.; Zhu, L.; Ni, G. Biophysical limits to responses of water flux to vapor pressure deficit in seven tree species with contrasting land use regimes. Agric. For. Meteorol. 2015, 200, 258-269. [CrossRef]

78. Shirke, P.A.; Pathre, U.V. Influence of leaf-to-air vapour pressure deficit on the biochemistry and physiology of photosynthesis in Prosopis juliflora. J. Exp. Bot. 2004, 55, 2111-2120. [CrossRef] [PubMed]

79. Damour, G.; Simonneau, T.; Cochard, H.; Urban, L. An overview of models of stomatal conductance at the leaf level. Plant Cell Environ. 2010, 33, 1419-1438. [CrossRef] [PubMed]

80. Novick, K.A.; Ficklin, D.L.; Stoy, P.C.; Williams, C.A.; Bohrer, G.; Oishi, A.C.; Papuga, S.A.; Blanken, P.D.; Noormets, A.; Sulman, B.N.; et al. The increasing importance of atmospheric demand for ecosystem water and carbon fluxes. Nat. Clim. Change 2016, 6, 1023-1087. [CrossRef]

81. Mott, K.A.; Peak, D. Stomatal responses to humidity and temperature in darkness. Plant Cell Environ. 2010, 33, 1084-1090. [CrossRef]

82. Rodríguez-Gamir, J.; Xue, J.M.; Clearwater, M.J.; Meason, D.F.; Clinton, P.W.; Domec, J.C. Aquaporin regulation in roots controls plant hydraulic conductance, stomatal conductance, and leaf water potential in Pinus radiata under water stress. Plant Cell Environ. 2019, 42, 717-729. [CrossRef] [PubMed]

83. Zekri, M.; Parsons, L.R. Growth and root hydraulic conductivity of several citrus rootstocks under salt and polyethylene glycol stresses. Physiol. Plant 1989, 77, 99-106. [CrossRef]

84. Rodríguez-Gamir, J.; Ancillo, G.; Legaz, F.; Primo-Millo, E.; Forner-Giner, M.A. Influence of salinity on PIP gene expression in citrus roots and its relationship with root hydraulic conductance, transpiration and chloride exclusion from leaves. Environ. Exp. Bot. 2012, 78, 163-166. [CrossRef]

85. Dodd, I.C. Root-to-shoot signalling: Assessing the roles of 'up' in the up and down world of long-distance signalling in planta. Plant Soil 2005, 274, 251-270. [CrossRef]

86. Liang, J.S.; Zhang, J.H.; Wong, M.H. How do roots control xylem sap ABA concentration in response to soil drying? Plant Cell Physiol. 1997, 38, 10-16. [CrossRef]

87. Castro, P.; Puertolas, J.; Dodd, I.C. Stem girdling uncouples soybean stomatal conductance from leaf water potential by enhancing leaf xylem ABA concentration. Environ. Exp. Bot. 2019, 159, 149-156. [CrossRef]

88. Buckley, T.N. Optimal carbon partitioning helps reconcile the apparent divergence between optimal and observed canopy profiles of photosynthetic capacity. New Phytol. 2021, 230, 2246-2260. [CrossRef] [PubMed] 
89. Allen, R.G.; Pereira, L.S.; Raes, D.; Smith, M. Crop Evapotranspiration Guidelines for Computing Crop Water Requirements; FAO Irrigation and Drainage Paper no 56; FAO: Rome, Italy, 1998; pp. 15-27.

90. Bastida, F.; Torres, I.F.; Abadía, J.; Romero-Trigueros, C.; Alarcón, J.J.; García, C.; Nicolás, E. Comparing the impacts of drip irrigation by freshwater and reclaimed waste-water on the soil microbial community of two citrus species. Agric. Water Manag. 2018, 203, 53-62. [CrossRef]

91. Maas, E.V. Salinity and citriculture. Tree Physiol. 1993, 12, 195-216. [CrossRef] [PubMed]

92. Scholander, P.F.; Hammel, H.T.; Bradstreet, E.D.; Hemmingsen, E.A. Sap Pressure in Vascular Plants: Negative hydrostatic pressure can be measured in plants. Science 1965, 148, 339-346. [CrossRef]

93. Turner, N.C. Measurements of plant water status by pressure chamber technique. Irrig. Sci. 1988, 9, 289-308. [CrossRef]

94. McCutchan, H.; Shackel, K.A. Stem-water potential as a sensitive indicator of water-stress in prune trees (Prunus-domestica L cv French). J. Am. Soc. Hort. Sci. 1992, 117, 607-611. [CrossRef]

95. Gucci, R.; Xiloyannis, C.; Flore, J.A. Gas-exchange parameters, water relations and carbohydrate paririoning in leaves of field-grown prunus-domestica following fruit removal. Physiol. Plant. 1991, 83, 497-505. [CrossRef]

96. Brodribb, T.J.; Holbrook, N.M. Stomatal closure during leaf dehydration, correlation with other leaf physiological traits. Plant Physiol. 2003, 132, 2166-2173. [CrossRef]

97. Quarrie, S.A.; Whitford, P.N.; Appleford, N.E.J.; Wang, T.L.; Cook, S.K.; Henson, I.E.; Loveys, B.R. A monoclonal-antibody to(s)-Abscisic Acid-its characterization and use in a radioimmunoassay for measuring abscisic-acid in crude extracts of cereal and lupin leaves. Planta 1988, 173, 330-339. [CrossRef] 